\title{
Василий Татищев, “искусной архитект” Фридриха Барбароссы и кто-то третий
}

\section{Vasilii Tatishchev, the "Skilled Architect" of Friedrich Barbarossa and a Third Personage}

\author{
Михаил Бойцов \\ Национальный исследовательский университет \\ Высшая школа экономики \\ Mikhail Boytsov \\ National Research University \\ Higher School of Economics \\ mboytsov@hse.ru
}

\begin{abstract}
:
The author attempts to find out under what circumstances Vasilii Tatishchev could have come to his assertion that Emperor Frederick I Barbarossa had sent an architect to Andrei Bogoliubskii, prince of Vladimir. Despite the wide popularity of this Tatishchev's argument among today's historians of architecture, it has never become the subject of a special study. Meanwhile, this case allows a deep look into the specific research methods of a historian in the first half of the eighteenth century, as well as into his narrative strategies and value orientations.
\end{abstract}

Keywords:

The culture of historical research in the eighteenth century, Vasilii Tatishchev, the "Tatishchev data," the "Volynskii conspiracy," Petr Eropkin, The Book of Degrees of the Royal Genealogy, Frederick I

Barbarossa, architectural monuments of Vladimir

Трудно найти публикацию о белокаменном зодчестве Владимиро-Суздальской Руси XII-XIII вв., в которой не приводилось бы одно смелое утверждение В. Н. Татищева (1686-1750). Согласно ему, не кто иной, как император Фридрих I Барбаросса (ок. 1122-1190) прислал зодчего владимирскому князю Андрею Боголюбскому (ок. 1111-1174), с каковым император, оказывается, состоял в дружбе. В серьезной литературе это заявление Татищева сопровождается обычно осторожными оговорками. Тем не менее, оно явно повлияло на таких историков архитектуры, как Н. Н. Воронин, А. И. Комеч и С. В. Заграевский, когда они указывали на германские земли, и прежде всего Рейнскую область, в качестве вероятной творческой родины создателя храма Покрова на Нерли.

Источник интригующего сообщения автора Истории Российской, как и сотен других его замечаний, неизвестен. Однако удивляет, что ни один специалист, ни по древнерусской архитектуре, ни по истории Владимиро-Суздальской Руси, ни по сомнительным “татищевским известиям” - до сих пор не попытался прояснить здесь хотя бы то немногое, что прояснить возможно. Разве не резонно спросить, когда и при каких обстоятельствах Татищев сформулировал свой тезис, возвращался ли он к нему, модифицировал ли его с течением времени? Считал ли его случайной догадкой или же серьезным открытием? Использовал 
ли свою находку, чтобы высказать какие-либо исторические, философские или политические взгляды?

Если же Татищев всецело выдумал эпизод о “дружбе” Барбароссы с Андреем Боголюбским, то в чем состояли мотивы и интересы автора, где он обрел источник вдохновения? Столь смелую игру воображения и саму по себе стоило бы признать гениальной, ведь Татищев никак не мог знать того, в чем уверены сегодняшние историки архитектуры: примерно в 1157 г. во Владимире действительно появились новые мастера, умевшие так возводить и украшать храмы, как это делали тогда в Италии, Франции и Германии. Мастерство приезжих было отнюдь не провинциального уровня: сохранись сегодня их постройки в любой из перечисленных стран, они благодаря своему художественному качеству не затерялись бы и там в длинном ряду романских памятников.

Цель этой статьи состоит, однако, вовсе не в том, чтобы разыскивать следы зодчих XII в. Подробный разбор одного-единственного тезиса В. Н. Татищева позволяет высветить методы работы и движение мысли русского историка первой половины XVIII в., определить, как его академические интересы сочетались с политическими симпатиями, увидеть на единичном примере, как формировалось то историческое знание, элементы которого не потеряли актуальности даже в наши дни. В самом деле, владимирские экскурсоводы и сегодня с удовольствием поведают туристам о зодчем, присланном Барбароссой. Правда, не все они упомянут имя человека, которому мы всецело обязаны этим не то блистательным открытием, не то досадным заблуждением, а, быть может, и вдохновенным домыслом. ${ }^{1}$

\section{1. Одно открытие в двух примечаниях}

Суждение Татищева о причастности Барбароссы к достижениям строительной артели князя Андрея Боголюбского известно всего лишь по двум примечаниям ко второй части татищевской Истории Российской, изданной немалыми усилиями Г. Ф. Миллера (1705-1783) в 1774 г. - т.е. почти через четверть века после кончины автора. Первое из них будет далее обозначаться как "Примечание А.” В издании оно стоит под номером 483 и читается следующим образом:

По оставшему во Владимире строению, а паче по вратам градским видимо, что Архитект достаточный был. Онаго древняго строения мало осталось, и починка новая весьма отменилась; церковь же, конечно, должна бы преимуществовать. Но как оная после некаким простым каменщиком перестроивана, то ныне уже ни коего знака науки архитектурной в ней не видно, мастеры же присланы были от

\footnotetext{
${ }^{1}$ В качестве общего введения в биографию и труды В. Н. Татищева, а также в бесконечные дискуссии вокруг его наследия см.: Михаил Б. Свердлов, “Василий Никитич Татищев - историк," в М. В. Ломоносов и становление исторической науки в России (Санкт-Петербург: НесторИстория, 2011), 439-520. (Mikhail B. Sverdlov, "Vasilii Nikitich Tatishchev - istorik," v M. V. Lomonosov i stanovlenie istoricheskoi nauki v Rossii (St. Petersburg: Nestor-Istoriia, 2011, 439-520).
} 
Императора Фридерика перваго, с которым Андрей в дружбе был, как ниже явится. ${ }^{2}$

Под “вратами градскими” следует понимать, конечно, Золотые ворота, но вот о какой церкви идет речь, из приведенной формулировки сразу не догадаться. Хотя строительство Золотых ворот датируется 1158-1164 гг. (т.е. временем, когда во Владимире уже работали приезжие мастера), историки архитектуры настаивают на участии в нем и старой артели Юрия Долгорукого (1090/1100-1157), трудившейся в Ростово-Суздальской земле до приезда туда “зодчего Барбароссы." $\mathrm{O}$ качестве ее построек можно судить по Борисоглебской церкви в Кидекше и Спасо-Преображенскому собору в Переяславле-Залесском, заложенным, видимо, практически одновременно в 1152 г.

Легко заметить, что "Примечание A" построено на двух принципиально различных типах данных. По большей части оно передает “сегодняшние” личные впечатления от осмотра “древняго строения” во Владимире. И только в самом конце появляется “историческое” утверждение, основу которого должно составлять некое старинное письменное свидетельство - если, конечно, автор здесь не разыгрывал читателя.

“Примечание A" относится к тому месту основного текста Истории, где Татищев в рубрике за 116о г. пересказывает широко известный летописный рассказ о возведении Успенского собора во Владимире. ${ }^{4}$ В отличие от летописца, Татищев не придает значения вере князя и его “тщанию к святой Богородице” все дело в его стараниях практического плана: “по снисканию бо его даде ему Бог мастеров для строения онаго из умных земель.” На внешнем поле страницы против этого абзаца проставлен “фонарик”: “Архитект во Владимире.” Однако

\footnotetext{
${ }^{2}$ Василий Н. Татищев, История Российская с самых древнейших времён, кн. 3 (Москва: Имп. Московский университет, 1774), 487. (Vasilii N. Tatishchev, Istoriia Rossiiskaia s samykh drevneishikh vremën, kn. 3 (Moscow: Imp. Moskovskii universitet, 1774), 487).

${ }^{3}$ См. Николай Н. Воронин, Зодчество Северо-Восточной Руси XII-XV веков, т. 1 (Москва: Академия Наук СССР, 1961), 132, 323-24. (Nikolai N. Voronin, Zodchestvo Severo-Vostochnoi Rusi XII$X V$ vekov, t. 1 (Moscow: Akademiia Nauk SSSR, 1961), 132, 323-24); Татьяна П. Тимофеева, Золотые ворота во Владимире (Москва: Северный паломник, 2002), 16. (Tat'iana P. Timofeeva, Zolotye vorota vo Vladimire (Moscow: Severnyi palomnik, 2002), 16); Сергей В. Заграевский, “Архитектор Фридриха Барбароссы,” в Хвалам достойный.... Андрей Боголюбский в русской истории и культуре. Международная научная конференция, Владимир, 5-6 июля 2011 года (Владимир: Государственный Владимиро-Суздальский музей-заповедник, 2013), 184-95. (Sergei V. Zagraevskii, "Arkhitektor Fridrikha Barbarossy," v Khvalam dostoinyi.... Andrei Bogoliubskii v russkoi istorii i kul'ture. Mezhdunarodnaia nauchnaia konferentsiia, Vladimir, 5-6 iiulia 2011 goda (Vladimir: Gosudarstvennyi Vladimiro-Suzdal'skii muzei-zapovednik, 2013), 184-95).

${ }^{4}$ Цитируем (в упрощенной орфографии) статью за 6668 г. по Радзивиловской летописи, копию которой Татищев внимательно изучал: “[В] то же лето созда бысть церкви святые Богородици в Володимири благовернымъ и христолюбивымъ княземъ Андреемъ, и украси ю дивно многоразличными иконами, и драгимъ каменьемъ бес числа, и сосуды церковными, и верхъ ея позлати. По вере же его и по дщанию ко святеи Богородици приведе ему богъ из умных земль мастеры и украси ю паче инехъ церквеи". Полное собрание русских летописей (далее - ПСРЛ), т. 38 (Ленинград: Наука, Ленинградское отделение, 1989), 130. (Polnoe sobranie russkikh letopisei (dalee - PSRL), t. 38 (Leningrad: Nauka, Leningradskoe otdelenie, 1989), 130).

${ }^{5}$ Татищев, История, 127. (Tatishchev, Istoriia, 127). Ср. вариант из Первой редакции будущей Истории Российской: "[...] по снисканию бо его приведе ему бог из умных земель мастеры, иже строиша и украсиша ю паче всех церквей [...].” В “фонарике” слово “архитект” дано во множественном числе. Василий Н. Татищев, История Российская в семи томах, т. 4 (Москва;
} 
откуда взялся Барбаросса в примечании? Может быть, Татищев просто обратил внимание на сообщение летописи о перестройке в 1194 г. разрушившегося от времени и небрежения суздальского собора? Летописец похвалил епископа Иоанна за то, что тот “не ища мастеров от Немець, но налезе мастеры от клеврет святое Богородицы и своих.” З Значит, раньше некий крупный и состоятельный заказчик искал “мастеров от Немець,” а кем же ему и быть, если не Андрею Боголюбскому? Тогда Татищеву стоило только поинтересоваться, кто же правил “немцами" при князе Андрее, чтобы легко прийти к умозаключению: зодчих должен был направить именно Фридрих І. Объяснение это, однако, слишком простое. Прежде всего, Татищев прекрасно знал, что “немцы” - этноним обобщенный, которым летописцы могли называть самые разные народы. ${ }^{7} \mathrm{~A}$ кроме того, как вскоре будет показано, морфология его утверждения куда сложнее.

Второе примечание - будем называть его впредь “Примечание Б” - стоит в издании под номером 547: “Цесарь был Фридерик Барбаросса, по нем сын его Генрик IV. сий же упоминает Послов от Цесаря и архитекты присланные, N. 483, чем дружбу сию утверждает." 1190 г. под именем Генриха VI (1165-1197), а с Генрихом IV (1050-1106) были связаны весьма драматичные события, читатель здесь может заподозрить, что Татищев вовсе не разбирался в истории германских земель. Однако из последующего станет ясно, что такие подозрения безосновательны.

оПри всей краткости “Примечания Б” в нем обнаруживается несколько странностей. Один “архитект" превратился в нескольких. Вместо дружбы Фридриха I с Андреем Боголюбским, которую автор обещал разъяснить “ниже,” в “Примечании Б” “утверждается” дружба уже между Генрихом VI и его владимирским контрагентом, которым мог быть только Всеволод Большое Гнездо (1154-1212). Далее оказывается, что во Владимир вместе с архитекторами были отправлены и послы, причем именно от Фридриха I. Что же до Генриха VI, то он только “упоминает” об этих событиях - очевидно, в какой-то грамоте. У слов о присланных архитекторах (а не у последующего упоминания о “дружбе” между государями) Татищев ставит отсылку выше, к “Примечанию А,” тогда как

Ленинград: Академия Наук СССР, 1964) (далее - Татищев 4), 258. (Vasilii N. Tatishchev, Istoriia Rossiiskaia v semi tomakh, t. 4 (Moscow: Leningrad: Akademiia Nauk SSSR, 1964) (dalee - Tatishchev 4), 258). Ошибочное предположение, будто у Татищева здесь слышен отголосок оборота "умный свет" из манифеста о вступлении на престол Елизаветы Петровны, см. в: Андрей В. Горовенко, Василий Татищев и “древние летописи": домонгольская Русь глазами первого русского историка (Санкт-Петербург: Олег Обышко, 2019), 292. (Andrei V. Gorovenko, Vasilii Tatishchev i "drevnie letopisi”: domongol'skaia Rus' glazami pervogo russkogo istorika (St. Petersburg: Oleg Obyshko, 2019), 292). Как раз в этом месте Татищев дословно следует летописи.

6 Летопись по Лаврентиевскому списку, изд. 3 (Санкт-Петербург: Археографическая комиссия, 1897), 39o. (Letopis' po Lavrentievskomu spisku, izd. 3 (St. Petersburg: Arkheograficheskaia komissiia, 1897), 390). Ср. также близкий вариант в Никоновской летописи, также использовавшейся Татищевым: ПСРЛ, т. 10 (Санкт-Петербург: типография Министерства внутрених дел, 1885), 21 (статья за 6701 г.). (PSRL, t. 10 (St. Petersburg: tipografiia Ministerstva vnutrennikh del, 1885), 21 (stat'ia za 6701 g.).

${ }^{7}$ См., например: “[...] иногда половцев и татар, за едино отродие кладут, хотя они никоего согласия в роде и языке не имели, власно как, и не весьма давно, у нас все европские так разные народы во едино имя немец заключали". Татищев 4, 411. (Tatishchev 4, 411).

${ }^{8}$ Татищев, История, 500. (Tatishchev, Istoriia, 500). 
“Примечание A" в свою очередь ссылалось на “Примечание Б,” поскольку ничего иного, хоть как-то относящегося к дружбе Гогенштауфенов и Юрьевичей, еще "ниже" уже более не “явится". Запомним эту странную закольцованную композицию, отметив заодно, что автор обманывает ожидания читателя: сначала он посулил разъяснить “ниже” характер отношений Барбароссы и Андрея, а в итоге не сказал на эту тему ничего нового, если не считать упоминания послов, якобы отправленных от первого ко второму.

“Примечание Б” относится к пересказу Татищевым под 1190 г. другого сюжета, известного благодаря Ипатьевской летописи, - о бегстве галицкого князя Владимира Ярославича из венгерского плена в “Немецкую землю” к “царю немецкому.” Согласно Татищеву, когда император узнал, что беглец “есть сестренич Всеволода Великого Князя Белоруского, о котором он любовь и частую переписку имел, принял его с честию и любовию великою." идет уже не о дружбе, а о любви, притом в новом сочетании - между Фридрихом Барбароссой и Всеволодом. Примечание должно было как раз разъяснить, какой именно император приветил Владимира Ярославича, поскольку 1190 г. оказался рубежным между двумя царствованиями. ${ }^{10}$ Заявить о наличии любви Фридриха I к владимирскому князю Татищев мог, исходя из простого умозаключения: раз император полюбил родственника Всеволода, значит, он любил и самого Всеволода. Зато замечание про переписку между ними, тем более “частую," выглядит тем подозрительнее, что в Первой редакции будущей его еще не было."

Не требуется особой проницательности, чтобы из сопоставления обоих примечаний, “А” и “Б”, догадаться, как могла выглядеть их документальная основа - если, конечно, таковая вообще имелась. Она должна была представлять собой лаконичный пересказ фрагмента послания императора Генриха VI, адресованного Всеволоду Юрьевичу. ${ }^{12}$ В нем император напоминал Всеволоду о “дружбе” между их предшественниками: императором Фридрихом I (отцом автора) и князем Андреем Юрьевичем или же Юрием Владимировичем (сводным братом или отцом адресата). В качестве яркого проявления той “дружбы” Генрих VI, надо полагать, “упомянул," как его отец направил на Русь мастеров-строителей. Собственная память подспорьем Генриху VI в данном случае быть никак не могла: если эпизод с отправкой зодчих вообще имел место, то лет за восемь до его рождения. Император не мог вычитать о нем и в копии грамоты, которой его отец должен был снабдить архитекторов, поскольку

\footnotetext{
${ }^{9}$ Там же, 293. (Tam zhe, 293). В Ипатьевской летописи: "Царь же уведав оже есть сестричич великому князю Всеволоду Суждальскому и прия его с любовью и с великою честью”. ПСРЛ, т. 2, изд. 2 (Санкт-Петербург: типография М. А. Александрова, 19o8), 666. (PSRL, t. 2, izd. 2 (St. Petersburg: tipografiia M. A. Aleksandrova, 1908), 666).

${ }^{10}$ В действительности бегство Владимира Ярославича произошло, видимо, еще в 1189 г. Подробнее об этом эпизоде см.: Michael Lindner, "Ein regulus Ruthenorum am Hofe Kaiser Friedrich Barbarossas. Das Wiener Dreikönigetreffen des Jahres 1165 und die 'Ostpolitik' des Staufers” Zeitschrift für Ostmitteleuropa-Forschung 50 (2001): 349, 357-59.

"1 “Царь же, уведав, иж есть сестренич великому князю Всеволоду суздальскому, с ним же царь велику любовь име, прият его с любовию и честию великою.” Татищев 4, 312. (Tatishchev 4, 312).

${ }^{12}$ Такое предположение уже делалось. См, например: Воронин, Зодчество, 331. (Voronin, Zodchestvo, 331).
} 
регистров исходящих писем в императорской канцелярии тогда еще не велось. ${ }^{13}$ Выходит, напомнить Генриху VI о событиях сорокалетней давности должен был какой-то долгожитель в его окружении, Адресат тоже не припомнил бы прибытия зодчих: ему тогда было года три от роду. Однако развернутое ими строительство он должен был видеть как до своего изгнания в 1162 г., так и после возвращения в пятнадцатилетнем возрасте. Да и при его правлении здания, воздвигнутые приезжими, были у всех на виду, говоря сами за себя.

Согласно замыслу Татищева, основной текст его труда основывался всецело на русских летописях, тогда как сведениям из иностранных источников отводилось место в примечаниях. ${ }^{4}$ В соответствии с этой логикой, следы грамоты Генриха VI стоило бы разыскивать в одной из тех немецких книг, что Татищев время от времени сам покупал или выписывал - то поштучно, то ящиками. ${ }^{15} \mathrm{~B}$ таких усилиях, однако, необходимости нет: самые тщательные поиски посланий не только Генриха VI, но и всех прочих средневековых императоров немецкие историки уже давно провели. Вероятность того, что издатели академического справочника Regesta Imperii пропустили какую-либо немецкую публикацию из известных Татищеву, ничтожно мала. Между тем во всех трех томах RI, посвященных правлению Генриха VI, никаких посланий русским князьям не

\footnotetext{
${ }^{13}$ Thomas Ertl, Studien zum Kanzlei- und Urkundenwesen Kaiser Heinrichs VI (Wien: Österreichische Akademie der Wissenschaften, 2002), 29.

${ }^{14}$ См. свидетельство Татищева еще 1734 года: “[...] гисторию рускую, которую ты хотя не в совершенном порядке, однако ж довольную в моих письмах найдешь, и ко иной примечании и дополнки [вариант: дополнении - М.Б.] из чужестранных книг, выписанные на разных бумагах, естьли охота будет, можешь в порядок собрать [...].” Василий Н. Татищев, “Духовная,” в: Василий Н. Татищев, Избранные произведения, ред. Сигизмунд Н. Валк (Ленинград: Наука, Ленинградское отделение, 1979) (далее - Татищев 8), 138. (Vasilii N. Tatishchev, "Dukhovnaia," v: Vasilii N. Tatishchev, Izbrannye proizvedeniia, red. Sigizmund N. Valk (Leningrad: Nauka, Leningradskoe otdelenie, 1979) (dalee - Tatishchev 8), 138). О таком же построении труда уже на стадии завершения говорится в письме 1746 г.: "История от начала росиских государей до нашествиа татар от многих руских манускрыптов древним наречием сочинена и от иностранных примечаниями изъяснена [...]" Василий Никитич Татищев. Записки. Письма. 1717-1750 г2. (Москва: Наука, 1990) (Научное наследство 14) (далее - Татищев 9), 321 (№ 229). (Vasilii Nikitich Tatishchev. Zapiski. Pis'ma. 1717-1750 gg.. (Moscow: Nauka, 1990) (Nauchnoe nasledstvo 14) (dalee Tatishchev 9), 321, nо. 229). См, наконец, в тексте самой Истории Российской: “[...] где что изъяснения или от чужестранных к доказательству требовалось, оное я, числами назнача, особно приобщил [...].” Татищев 4, 39. (Tatishchev 4, 39). Ср.: Александр И. Андреев, “Труды В. Н. Татищева по истории России” в: Василий Н. Татищев, История Российская в семи томах, т. 1 (Москва-Ленинград: Академия Наук СССР, 1962) (далее - Татищев 1), 25-26 (Aleksandr I. Andreev, "Trudy V. N. Tatishcheva po istorii Rossii” v Vasilii N. Tatishchev, Istoriia Rossiiskaia v semi tomakh, t. 1 (Moscow-Leningrad: Akademiia Nauk SSSR, 1962) (dalee - Tatishchev 1), 25-26); Сигизмунд Н. Валк, “О составе рукописей седьмого тома Истории Российской В. Н. Татищев” в: Василий Н. Татищев, История Российская в семи томах, т. 7 (Москва-Ленинград: Академия Наук СССР, 1968) (далее Татищев 7), 31. (Sigizmund N. Valk, "O sostave rukopisei sed'mogo toma "Istorii Rossiiskoi" V. N. Tatishcheva” v Vasilii N. Tatishchev, Istoriia Rossiiskaia v semi tomakh, t. 7 (Moscow-Leningrad: Akademiia Nauk SSSR, 1968) (dalee - Tatishchev 7), 31).

${ }^{15}$ О библиотеке Татищева на Урале см.: Алевтина М. Сафронова, Личная библиотека В. Н. Татищева в Екатеринбурге (Екатеринбург: Уральский университет, 2017). (Alevtina M. Safronova, Lichnaia biblioteka V. N. Tatishcheva v Ekaterinburge (Ekaterinburg: Ural'skii universitet, 2017)). O составе самарской библиотеки, перевезенной в Москву, можно судить по каталогу, составленному вскоре после смерти Татищева: Петр П. Пекарский, Новые известия о В. Н. Татищеве (Санкт-Петербург: Имп. Академия наук, 1864), 56-63. (Petr P. Pekarskii, Novye izvestiia o V. N. Tatishcheve (St. Petersburg: Imp. Akademiia nauk, 1864), 56-63).
} 
упоминается. ${ }^{16}$ Более того, и в служебной картотеке возможных дополнений для будущих переизданий ничего сколько-нибудь подходящего тоже не обнаружилось. ${ }^{17}$ Тем самым поиски предполагаемого источника татищевского суждения остается вести все-таки на российской почве.

\section{2. Немецкие примечания к русской истории}

Вполне готовую - как тогда казалось автору - рукопись единственно нас интересующей (нынешней второй) части Гистории древнейшей Татищев привез с собой в Петербург в конце января или начале февраля 1739 г. Ему пришлось покинуть Самару из-за обвинений в злоупотреблениях, допущенных во главе доверенной ему в 1737 г. Оренбургской экспедиции (уже переименованной в комиссию) ${ }^{18}$ Претензий к Татищеву накопилось столько, что 27 мая 1739 г. была созвана особая сенатская комиссия из шести человек “для рассмотрения дел и доношений, касающихся действий тайного советника Василия Татищева."19 Тем не менее, в те же нервные месяцы, по признанию самого Татищева, он занимался доработкой готовых разделов Истории: “многим оную показывал, требуя к тому помосчи и разсуждения, дабы мог что пополнить, а невнятное изъяснить”. Критических замечаний Татищеву пришлось выслушать немало: "Иному то, другому другое ненравно было." ${ }^{\circ}$ Однако нашлись и знатоки, “снискательные к гистории русской,” оказывавшие ему поддержку, делившиеся с ним не только собственными знаниями, но и рукописными коллекциями. Среди них были и вскоре “в несчастие впадшие” давние знакомые Татищева обер-егермейстер и кабинет-министр А. П. Волынский (1689-1740), архитектор, полковник и гофбауинтендант П. М. Еропкин (1689-1740), капитан флота и советник Экипажмейстерской конторы А. Ф. Хрущов (1691-1740). С их помощью Татищев совершенствовал, вероятно, не только основной текст своего труда, но и примечания к нему, тоже привезенные более или менее готовыми из Самары. ${ }^{21}$

На протяжении почти всего петербургского пребывания Татищев числился подследственным, жил какое-то время под домашним арестом, вызывался на допросы и очные ставки. В апреле 1740 г. прошел слух, что его заключили в крепость. При этом в те же самые месяцы в столице империи происходили

\footnotetext{
${ }^{16}$ См. указатель имен и географических названий: Die Regesten des Kaiserreiches unter Heinrich VI. 1165 (1190)-1197. Namenregister, Ergänzungen und Berichtigungen, Nachträge, bearb. von Karin und Gerhard Baaken (Cologne-Vienna: Böhlau, 1979) (J. F. Böhmer, Regesta Imperii IV: Ältere Staufer, Abt. 3), $1-183$.

${ }^{17}$ Выражаю признательность профессору Г. Лубиху (Университет Рурской области в Бохуме), любезно проверившему эту картотеку.

${ }^{18} 3$ января 1739 г. Татищев был еще в Самаре. См.: Татищев 9, 272-74 (№ 175-76). (Tatishchev 9, 27274, no. 175-76). В Санкт-Петербурге он оказался не позже 15 февраля. См.: там же, 274 (№ 177). (Sm.: tam zhe, 274, no. 177).

${ }^{19}$ Опись высочайшим указам и повелениям, хранящимся в С.-Петербургском Сенатском архиве, за XVIII век, составил Платон И. Баранов, т. 2, 1725-1740 (Санкт-Петербург: типография Правительствующего Сената, 1875), 592 (№ 7035). (Opis' vysochaishim ukazam i poveleniiam, khraniashchimsia v S.-Peterburgskom Senatskom arkhive, za XVIII vek, sostavil Platon I. Baranov, t. 2, 1725-1740 (St. Petersburg: tipografiia Pravitel'stvuiushchego Senata, 1875), 592, no. 7035). Подробности см.: Горовенко, Василий Татищев, 99-129. (Gorovenko, Vasilii Tatishchev, 99-129).

${ }^{20}$ Татищев 1, 85. (Tatishchev 1, 85).

${ }^{21}$ Валк, "О составе рукописей," зо. (Valk, “O sostave rukopisei,” зо).
} 
события одно драматичнее другого, причем все они могли так или иначе сказаться на его судьбе, а некоторые, судя по всему, действительно сказались. В апреле 1740 г. был низвергнут Волынский, и до июня шло беспощадное следствие над ним и его “конфидентами,” в числе которых при неблагоприятном развитии событий Татищев тоже мог оказаться. Присутствовал ли он утром 27 июня 1740 г. в толпе на Сытном рынке, когда его “снискательные к гистории русской” приятели лишились голов один за другим? Не прошло и четырех месяцев, как 17 октября скончалась благоволившая Татищеву Анна Иоанновна и императором провозгласили Иоанна Антоновича (1740-1764) при регентстве Э. И. Бирона (1690-1772), Татищеву уже вовсе не благоволившего. Ничего хорошего историку от нового правителя ждать не приходилось. Однако уже 9 ноября 1740 г. Бирон был арестован и отправлен в ссылку. Новая регентша Анна Леопольдовна простила Татищева и 31 июля 1741 г. назначила ему ехать в Царицын возглавлять Калмыцкую комиссию. Не успеет еще Татищев более или менее освоиться на месте новой службы, как 25 ноября 1741 г. Анну Леопольдовну вместе с Иоанном Антоновичем свергнет Елизавета Петровна. Вскоре выяснится, что особой благосклонности она к Татищеву не питает...

Прибыв в начале 1739 г. из Самары в столицу империи, Татищев не прервал начавшуюся еще в 1730 г. переписку с влиятельным секретарем канцелярии Санкт-Петербургской Академии наук И. Д. Шумахером (1690-1761). ${ }^{22}$ В частности, Татищеву очень хотелось подключить академиков к исправлению рукописи своего труда. В их помощи применительно к основному тексту будущей второй части Истории он не нуждался - очевидно, не без оснований полагая, что в летописях разбирается заведомо лучше них. Зато вводный исторический обзор до княжения Рюрика (из него со временем вырастет первая часть Истории Российской), а также примечания к уже написанному внушали Татищеву беспокойство: он был заинтересован в критическом взгляде на них специалистов, лучше него разбиравшихся в истории всеобеей.

Для опасений основания имелись. Татищев был самоучкой: он учился на ходу, по книгам и рукописям, не прослушав ни единого курса по истории, не позанимавшись ни в одном историческом семинаре. С историей как университетской дисциплиной Татищев смог впервые познакомиться лишь во время пятнадцатимесячного пребывания в Швеции в 1724-1726 гг. ${ }^{23}$ По его собственным словам, он “имел случай со многими учеными разговаривать" не только в Уппсале, но и в Копенгагене, куда, видимо заехал из Мальмё в октябре

\footnotetext{
${ }^{22}$ См. о нем, а также и об отношениях Татищева с другими членами Академии Наук: Conrad Grau, Der Wirtschaftsorganisator, Staatsmann und Wissenschaftler Vasilij N. Tatiščev, 1686-1750 (Berlin: Akademie, 1963), 115-145. Сравни: Юрий Н. Столяров, "Вклад И. Д. Шумахера в развитие русской науки и культуры. (К 325-летию со дня рождения первого российского библиотекаря и библиотековеда)," Научные и технические библиотеки. № 9 (2015): 34-5o. (Iurii N. Stoliarov, "Vklad I. D. Shumakhera v razvitie russkoi nauki i kul'tury. (K 325 -letiiu so dnia rozhdeniia pervogo rossiiskogo bibliotekaria i bibliotekoveda)," Nauchnye i tekhnicheskie biblioteki, no. 9 (2015):34-50).

${ }^{23}$ Подробно об этом см: Grau, Der Wirtschaftsorganisator, 42-54; Александр Юхт, Государственная деятельность В. Н. Татищева в го-х - начале зо-х годов XVIII в. (Москва, 1985), 156-89. (Aleksandr Iukht, Gosudarstvennaia deiatel'nost' V. N. Tatishcheva v 2o-kh - nachale 3o-kh godov XVIII v. (Moscow, 1985), 156-89); Юрий Китнер, “Татищев в Швеции (1724-1726),” в Архангельск в XVIII в. (СанктПетербург, 1997), 318-412. (Iurii Kitner, "Tatishchev v Shvetsii (1724-1726)", v Arkhangel'sk v XVIII v. (St. Petersburg, 1997), 318-412); Свердлов, “Татищев - историк," 451-55 (Sverdlov, "Tatishchev - istorik," 451-455).
} 
1725 г. $^{24}$ Значение тех, безусловно важных, встреч и библиотечных занятий для становления Татищева как историка не стоит все же преувеличивать: в ходе шведской командировки он был перегружен другими задачами, требовавшими много времени и сил. К тому же специальных исторических дисциплин в России еще практически не существовало, что крайне затрудняло применение к русской истории источниковедческих методов, выработанных к тому времени западноевропейскими историками. Что же до знания в России истории всеобщей, то волна переводов новой зарубежной литературы и исторических источников на русский язык при Татищеве только еще поднималась, причем не без его собственного участия. ${ }^{25}$ Впрочем, не меньшей проблемой были (а отчасти и остаются до сих пор) и переводы работ российских историков на западноевропейские языки - именно с ней Татищев и столкнется в 1739 г. Ведь поскольку члены Санкт-Петербургской Академии наук не были сильны в русском языке, введение к труду Татищева (у него оно называлось “Предъизвещение”) и примечания потребовалось перевести на немецкий.

Ни русского оригинала примечаний к интересующей нас части, ни предшествовавших ему подготовительных вариантов обнаружить до сих пор не удалось, отчего самый ранний известный сегодня вариант примечаний “А” и “Б” доступен лишь в немецком переводе для академиков, отразившем одну из предварительных редакций будущей второй части Истории Российской. ${ }^{26}$ Перевод сохранился в беловой рукописи, описанной еще в 6о-е гг. XX в. ${ }^{27}$ В этом внушительном кодексе в картонном переплете переписаны немецкие версии как раннего варианта “Предъизвещения," так и примечаний. ${ }^{28}$ Текст их был

${ }^{24}$ Татищев 1, 349. (Tatishchev 1, 349); Юхт, Государственная деятельность, 182, 343 (Iukht, Gosudarstvennaia deiatel'nost', 182, 343).

${ }^{25}$ Подробно см.: Wim Coudenys, "Translation and the Emergence of History as an Academic Discipline in 18th-century Russia," Kritika: Explorations in Russian and Eurasian History 17 (2016): 721-52 или русский перевод: Вим Куденис, “Переводчики XVIII в. и становление историографии как науки в России," Quaestio Rossica 4, no 1 (2016): 235-6o; 4, no 2 (2016): 209-30. (Wim Coudenys, "Perevodchiki XVIII v. i stanovlenie istoriografii kak nauki v Rossii," Quaestio Rossica 4, no. 1 (2016): 235-6o; 4, no. 2 (2016): 209-30).

${ }^{26}$ Даже если подтвердится гипотеза, что фрагмент Татищева “Сокращение гистории русской," включавший комментарии, представлял собой исходную редакцию будущей Истории Российской, он нам бесполезен, поскольку изложение обрывается уже на 1111 г. См.: Владимир С. Астраханский, “Предварительная редакция “Истории Российской” В. Н. Татищева (1726-1727 гг.)," в Астраханский, "История Российская" B. H. Татищева: опыт текстологических, историографических и библиографических изысканий: сборник научных статей, под общей редакцией Марианны Д. Татищевой (Москва, 1993), 6-35 (Vladimir S. Astrakhanskii, "Predvaritel'naia redaktsiia "Istorii Rossiiskoi" V. N. Tatishcheva (1726-1727 gg.)," v Astrakhanskii, "Istoriia Rossiiskaia" V. N. Tatishcheva: opyt tekstologicheskikh, istoriograficheskikh i bibliograficheskikh izyskanii: sbornik nauchnykh statei, pod obshchei redaktsiei Marianny D. Tatishchevoi (Moscow, 1993), 6-35); Евгений М. Добрушкин (подгот., введ.), “Неопубликованная рукопись В. Н. Татищева по русской истории,” Советские архивы 5 (1971): 88-95. (Evgenii M. Dobrushkin (podgot., vved.), "Neopublikovannaia rukopis' V. N. Tatishcheva po russkoi istorii," Sovetskie arhivy 5 (1971): 88-95).

${ }^{27}$ См. ее описания: Татищев 4, 18 (Tatishchev 4, 18); Татищев 7, 32 (Tatishchev 7, 32).

${ }^{28}$ Российский государственный архив древних актов (РГАДА), ф. 181, Рукописный отдел библиотеки Московского Главного архива Министерства иностранных дел, оп. 16, д. 1374. (Rossiiskii gosudarstvennyi arkhiv drevnikh aktov (RGADA), f. 181, Rukopisnyi otdel biblioteki Moskovskogo Glavnogo arkhiva Ministerstva inostrannykh del, op. 16, d. 1374). "Derer alten Rußischen Annalium Zweyter Theil.” Под этим заголовком дается разъяснение: “т.е. древних Российских летописцев вторая часть, содержащая примечания Г. Татищева.” Затем другой рукой было в 
опубликован только в обратном переводе на русский язык И.В. Валкиной, местами точном, местами шероховатом, а местами просто ошибочном. ${ }^{29}$ Поскольку рукопись нашлась не в Академии наук, а в Московском архиве Коллегии иностранных дел, надо полагать, что Миллер, готовивший публикацию труда Татищева, взял ее с собой, переезжая в Москву. ${ }^{30}$

Дошедшую беловую рукопись можно датировать концом 1741 или началом 1742 г. (что подробно обосновывается далее), хотя работа над переводом началась еще поздней осенью 1739 г. $^{31}$ Во всяком случае, 21 ноября 1739 г. Татищев направляет Шумахеру “Предъизвещение” с просьбой о переводе его на немецкий язык, заодно сообщая, что примечания также готовы, и их как раз переписывают набело. ${ }^{32}$ Следующее письмо прилагалось уже к законченным комментариям: "При сем посылаю примечании на гисторию, которые переведши, изволите сообщить кому в посторонних гисториях лучше сведусчему, чтоб исправил и по

скобках после “летописцев” добавлено: “на Немецком языке,” а после “примечания” вставлено: "на Историю”. Еще одна пометка сделана красными чернилами рядом с именем Татищева. Ее автор счел нужным указать, что примечания "вероятнее” относятся к труду не Татищева, а А. Л. Щлёцера (1735-1809) (verosimilius Schlözeri), сославшись для обоснования своего предположения на последнюю строку четвертого листа и первую строку пятого. Сами эти строки не лишены ценности для определения времени написания рукописи: “[...] solches habe in mei- /ner Erklährung des von Je-/ROSLAW // PROMULGIERTen Gesetzes er-/wiesen [...].” Действительно, Шлёцер первым издал "Русскую правду" в 1767 г., но именно Татищев в 1737 г. обнаружил "закон, промульгированный Ярославом”, как он ее здесь называет. Поскольку здесь говорится об изъяснении (Erklährung) этого “закона”, понятно, что автор ссылается на первый вариант своего “Собрания законов древних русских", переданный им в Академию в 1740 г. Удивительно, что в академическом издании совершенно безосновательно утверждается, будто "на указанных листах рукописи читается пометка Шлёцера.” (Татищев 7, 32) (Tatishchev 7, 32). Ошибочное впечатление у читателя, будто на немецкий язык был переведен весь текст второй части, а не одни лишь комментарии к ней, создается в работах: Михаил Б. Свердлов, Василий Никитич Татищев автор и редактор "Истории Российской" (Санкт-Петербург: Европейский дом, 2009), 65 (Mikhail B. Sverdlov, Vasilii Nikitich Tatishchev - avtor i redaktor "Istorii Rossiiskoi" (St. Petersburg: Evropeiskii dom, 2009), 65); Свердлов, “Татищев - историк," 472. (Sverdlov, “Tatishchev - istorik,” 472). Выражаю глубокую признательность Е. В. Акельеву и О. Е. Кошелевой за исключительно любезную помощь в идентификации этой рукописи (у нее с 6о-х гг. прошлого века сменился шифр) и за возможность с ней ознакомиться.

${ }^{29}$ Татищев 7, 74-146. (Tatishchev 7, 74-146). Далее все переводы с немецкого - мои.

$3^{30}$ Подробнее о Г. Ф. Миллере и его роли в становлении российской исторической науки см.: Александр Б. Каменский, “Судьба и труды историографа Герарда Фридриха Миллера (1705-1783)," в Герард Ф. Миллер, Сочинения по истории России. Избранное (Москва: Наука, 1996), 374-416. (Aleksandr B. Kamenskii, "Sud'ba i trudy istoriografa Gerarda Fridrikha Millera (1705-1783)," v Gerard F. Miller, Sochineniia po istorii Rossii. Izbrannoe (Moscow: Nauka, 1996), 374-416); Симон С. Илизаров, Герард Фридрих Миллер (1705-1783) (Москва: Янус-К, 2005). (Simon S. Ilizarov, Gerard Fridrikh Miller (1705-1783) (Moscow: Ianus-K, 2005); Peter Hoffmann, Gerhard Friedrich Müller (1705-1783): Historiker, Geograph, Archivar im Dienste Russlands (Frankfurt am Main: Peter Lang, 2005).

${ }^{31}$ Филигрань “КОМЕРЦКОЛЕГИІ” на каждом листе мало дает для датировки рукописи, поскольку такая бумага выпускалась на протяжении 1736-1741 гг. См. Сократ А. Клепиков, Филиграни и штемпели на бумаге русского и иностранного производства XVII-XX века (Москва: Наука, 1978), 30 (№ 393). (Sokrat A. Klepikov, Filigrani i shtempeli na bumage russkogo i inostrannogo proizvodstva XVII-XX veka (Moscow: Nauka, 1978), 30, no. 393). (Любезно указано О. Е. Кошелевой.)

32 "При сем посылаю Пред[ъ]извесчение гистории русской, которое мню что перевести, и в гистории древней искуснейшему, разсмотря, исправить. [...] Гисторию если бы токмо писец был, то бы я готов и ее, а примечании набело дописывают. Но понеже и оные прежде равномернаго с Пред[ъ]извесчением разсмотрения требуют, то не ожидая переписки гистории пришлю." Татищев 9, 275-76 (№ 180). (Tatishchev 9, 275-76, no. 180). 
его искусству дополнил." ${ }^{3}$ Хотя письмо и без даты, его можно отнести к декабрю 1739 г., поскольку со следующим посланием - от 14 января 1740 г. - Татищев отправляет только что переписанную набело часть Гистории - но не для перевода, а в помощь переводчику, чтобы тот лучше понимал содержание примечаний. ${ }^{34}$ Имя переводчика известно: Шумахер поручил работу советнику камер-коллегии (с 1741 г. ее вице-президенту, а с 1764 г. президенту) Ф. И. фон Эмме (1699-1767). ${ }^{35}$ Работа фон Эмме затянется - вероятно, не в последнюю очередь потому, что Татищев время от времени досылал ему новые примечания, чему ниже будет приведен яркий пример.

Таблица 1. “Примечание A” в немецкой рукописи.

Текст и обратный перевод

\begin{tabular}{|c|c|}
\hline \multicolumn{2}{|l|}{ Примечание № $272 .{ }^{36}$} \\
\hline Немецјкий текст & Обратный перевод с немецукого \\
\hline $\begin{array}{l}\text { Dieses ist wohl Anmerckens werth, } \\
\text { / woher doch ANDREAS einen ARCHITECT / } \\
\text { genommen, denn die von ihm nachge- / } \\
\text { bliebene Gebäude zumahl die Stadt / } \\
\text { Pforte, sind nach der damahligen Zeit // } \\
\text { allerdings zubewundern, und man / } \\
\text { möchte solche wohl von einem erfare / } \\
\text { nen Zeichen-Meister abnehmen und / } \\
\text { zum Andencken in Kupffer stechen / } \\
\text { laßen. Die Kirche möchte auch außer- / } \\
\text { allem Zweiffel EXCELLENT seyn, allein / sie } \\
\text { nach wohl bey der INVASION des / BATI } \\
\text { beschädiget und hernach wieder / } \\
\text { ausgebessert und REPARIRet worden / } \\
\text { seyn, wordurch ein vieles von ihrer / alten } \\
\text { Pracht verlohren gangen, weil / ich } \\
\text { indeßen aber keine Zeit gehabet sie / mit } \\
\text { ATTENTION zubedrachten, so kann / ich } \\
\text { auch nichts umständtliches davon / } \\
\text { sagen; Gleichergestallt ist auch die / von } \\
\text { seinem Vater in JURIEFF POLSCOI / } \\
\text { gebauete Kirche sehens und bewun- / } \\
\text { derns werth. }\end{array}$ & $\begin{array}{l}\text { Заслуживало бы, пожалуй, } \\
\text { примечания, откуда же Андрей взял } \\
\text { архитектора, поскольку оставшиеся } \\
\text { после него постройки, особенно } \\
\text { городские ворота, для того времени, } \\
\text { конечно же, вызывают восхищение, и } \\
\text { надо бы опытному рисовальщику } \\
\text { запечатлеть их и для памяти } \\
\text { выгравировать на меди. Церковь, вне } \\
\text { всякого сомнения, тоже должна была } \\
\text { быть превосходной, но ее повредили, } \\
\text { вероятно, при вторжении Батыя, после } \\
\text { чего снова подправили и починили, в } \\
\text { результате чего утрачено многое из ее } \\
\text { древней красы. Поскольку между тем у } \\
\text { меня не было времени рассмотреть ее } \\
\text { со вниманием, то не могу и сказать о } \\
\text { ней ничего обстоятельного. Точно так } \\
\text { же и церковь, выстроенная в Юрьеве- } \\
\text { Польском его отцом, достойна } \\
\text { внимания и восхищения. }\end{array}$ \\
\hline
\end{tabular}

В Библиотеке Академии Наук, в составе Воронцовского собрания, исследователи творчества Татищева давно уже обнаружили другую, более позднюю, рукопись примечаний, отразившую авторскую правку на стадии

\footnotetext{
33 Там же, 276 (№ 181). (Tam zhe, 276, no. 181).

34 "При сем же посылаю гистории 13 тетрадей, которые при исправлении примечаней, мню, надобны [...].” Там же, 277 (№ 182). (Tam zhe, 277, no. 182).

35 Татищев 1, 25-26 (Tatishchev 1, 25-26); Татищев 4, 16 (Tatishchev 4, 16); Татищев 7, 32. (Tatishchev $7,32)$.

${ }^{36}$ РГАДА, ф. 181, оп. 16, д. 1374, л. 230-230 об. (RGADA, f. 181, op. 16, d. 1374, 1. 230-230 ob.).
} 
перехода от Первой редакции Гистории ко Второй. При этом манускрипт, судя по всему, сохранил ряд чтений из предыдущих редакций, включая тот самый русский оригинал, с которого несколькими годами ранее заказывался перевод на немецкий. 37 Выделим полужирным шрифтом части приведенного выше обратного перевода на сегодняшний русский язык, которые, судя по всему, можно заменить собственными словами Татищева из "Воронцовского списка."

Таблица 2. Сохранившиеся чтения русского оригинала "Примечания A"

\begin{tabular}{|c|c|}
\hline Обратный перевод с немецукого & “Воронцјовский список” \\
\hline & Примечание № $341^{38}$ \\
\hline $\begin{array}{l}\text { Заслуживало бы, пожалуй, } \\
\text { примечания, откуда же Андрей взял } \\
\text { архитектора, поскольку оставшиеся } \\
\text { после него постройки, особенно } \\
\text { городские ворота, для того времени, } \\
\text { конечно же, вызывают восхищение, } \\
\text { и надо бы опытному рисовальщику } \\
\text { срисовать их для памяти и } \\
\text { выгравировать на меди. Церковь, вне } \\
\text { всякого сомнения, тоже должна } \\
\text { была быть превосходной, но ее } \\
\text { повредили, п् вероятно } \\
\text { вторжении Батыя, после чего снова } \\
\text { подправили и починили, в } \\
\text { результате чего утрачено многое из ее } \\
\text { древней красы. Поскольку между тем } \\
\text { у меня не было времени рассмотреть ее } \\
\text { со вниманием, то не могу и сказать о } \\
\text { ней ничего обстоятельного. Точно так } \\
\text { же и церковь, выстроенная в Юрьеве- } \\
\text { Польском его отцом, достойна } \\
\text { внимания и восхищения. }\end{array}$ & $\begin{array}{l}\text { Сие примечание достойно, что } \\
\text { Андрей имел архитекта по дружбе от } \\
\text { императора Фридерика Барбароссы, } \\
\text { как н. } 382, \text { и видимо, что архитект был } \\
\text { искусной, ибо оставшие его } \\
\text { строения, а наипаче ворота } \\
\text { градские, по тогдашнему времяни } \\
\text { удивления достойны (паче же для } \\
\text { памяти, и ежели бы оное искусному } \\
\text { срисовать и напечатать). Церковь же } \\
\text { оная конечно должна бы оным } \\
\text { преизяществовать, но как оная } \\
\text { после перестроивана, потом от Батыя } \\
\text { созжена и повреждена, а после } \\
\text { починивана, то ея великолепия и } \\
\text { того, чтоб с архитекторою согласовало, } \\
\text { ничего не видно. }\end{array}$ \\
\hline
\end{tabular}

\footnotetext{
${ }^{37}$ Подробнее об этом списке см.: Сигизмунд Н. Валк, “О рукописях второй редакции второй части Истории российской В. Н. Татищева,” в Василий Н. Татищев, История Российская в семи томах, т. 2 (Москва-Ленинград: Академия Наук СССР, 1963) (далее - Татищев 2), 10-11, 18-19 (Sigizmund N. Valk, "O rukopisiakh vtoroi redaktsii vtoroi chasti "Istorii rossiiskoi" V. N. Tatishcheva," v Vasilii N. Tatishchev, Istoriia Rossiiskaia v semi tomakh, t. 2 (Moscow-Leningrad: Akademiia Nauk SSSR, 1963) (dalee - Tatishchev 2), 10-11, 18-19); Валк, "О рукописях первой редакции второй части Истории Российской В. Н. Татищева," в Татищев 4, 19 (Valk, "O rukopisiakh pervoi redaktsii vtoroi chasti “Istorii Rossiiskoi” V. N. Tatishcheva," v Tatishchev 4, 19). См. также факсимиле отдельных страниц этой рукописи: Татищев 2, 196-97, 273 (Tatishchev 2, 196-97, 273); Василий Н. Татищев, История Российская в семи томах, т. 3 (Москва- Ленинград: Академия Наук СССР, 1964) (далее - Татищев 3), 243, 245, 255, 271-72 (Vasilii N. Tatishchev, Istoriia Rossiiskaia v semi tomakh, t. 3 (MoscowLeningrad: Akademiia Nauk SSSR, 1964) (dalee - Tatishchev 3), 243, 245, 255, 271-72); Татищев 4, 33 (Tatishchev 4, 33); Свердлов, “Татищев - историк," 498-501. (Sverdlov, “Tatishchev - istorik," 498-501). ${ }^{38}$ Татищев 4, 444-45. (Tatishchev 4, 444-45).
} 
Скорректировав сегодняшний перевод собственными словами Татищева, далее можно при цитировании немецкой рукописи воспроизводить некоторые ее места довольно точно к гипотетическому исходному татищевскому тексту (не забывая, конечно, что это все же только его реконструкция).

Первым делом в немецком примечании бросается в глаза отсутствие упоминания Фридриха Барбароссы. Вместо категорического утверждения о роли императора Татищев лишь задает риторический вопрос, откуда князь Андрей мог взять столь искусного зодчего? Однако не стоит спешить с выводом, будто Татищев, составляя это примечание, еще ничего не знал о присылке архитектора Штауфеном. Сначала необходимо свериться с немецким “Примечанием Б.”

Это будет сделано чуть позже, а пока обратим внимание на то, в каком синтаксическом отдалении друг от друга оказались “сын” (Андрей) и “отец" (Юрий). Такое обычно происходит, когда изначально короткую запись разбивают вставкой. Здесь вставок было две, судя по тому, что затрагиваются две совсем разные темы.

Во-первых, говорится о необходимости зарисовать и растиражировать в виде гравюр облик владимирского “строения”. Во-вторых, Татищев делится собственными впечатлениями от владимирской архитектуры. Самое удивительное, что обе эти вставки можно примерно датировать, представляя тем самым каждый сюжет немецкого “Примечания A" в качестве отдельного хронологического слоя. Пусть небольшие несоответствия между формулировками из “Воронцовского списка" и немецким текстом нас не смущают: в данном случае важно лишь, как распределялись во времени блоки информации, а не как точно выглядел исходный текст каждого из таких блоков. ${ }^{39}$

Таблица 3. Хронологические слои в "Примечании А"

\begin{tabular}{|c|c|c|c|c|}
\hline лои & 1739 г. или ранее & $\begin{array}{l}\text { конец } 1739 \text { - начало } \\
1740 \text { г. }\end{array}$ & ноябрь 1740 г. & $\begin{array}{l}\text { после } 12 \text { сентября } 1741 \\
\text { г. }\end{array}$ \\
\hline & Сие примечание достойно, & & & \\
\hline 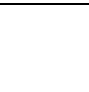 & & $\begin{array}{l}\begin{array}{l}\text { откуда } \\
\text { архитектора, }{ }^{*}\end{array} \text { Андрей } \\
\end{array}$ & & \\
\hline$\cdot$ & $\begin{array}{l}\text { ибо оставшие его строения, } \\
\text { а наипаче ворота градские, } \\
\text { по тогдашнему времяни } \\
\text { удивления достойны. }\end{array}$ & & & \\
\hline - & & & $\begin{array}{l}{[\ldots] \text { паче же для памяти, и }} \\
\text { ежели бы оное искусному } \\
\text { срисовать и напечатать [...] }\end{array}$ & \\
\hline - & & & & 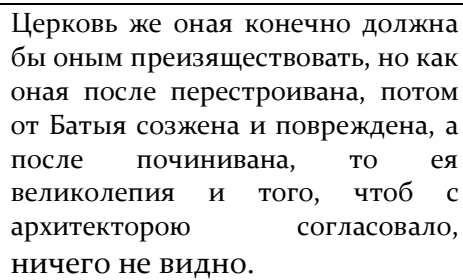 \\
\hline
\end{tabular}

\footnotetext{
39 Здесь и далее звездочкой отмечены обратные переводы с немецкого тех мест, для которых не обнаруживается соответствий в русских текстах Татищева.
} 


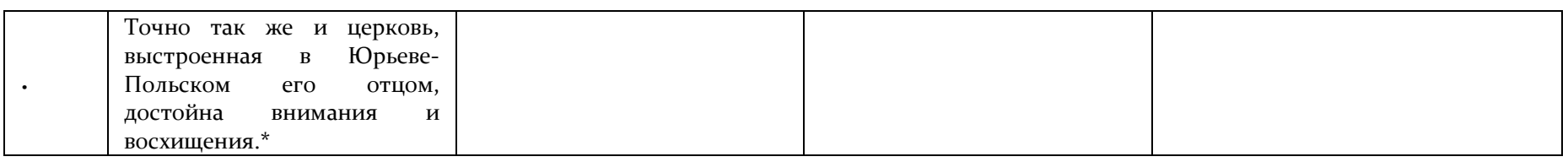

Первая вставка (слой 4) должна относиться примерно к тому же времени, что и письмо Шумахеру от 19 ноября 1740 г., в котором Татищев впервые ставит перед своим корреспондентом вопрос о фиксации облика памятников. Татищев предлагает Академии взять на себя подготовку приложения к его историческому труду (и прежде всего к интересующей нас второй части): “Но при том весьма бы нуждно некоторых древних строений чертежи приложить [...] Междо строениями руски[ми] в Володимере [соборная] церковь и ворота, в Юрьеве церковь." 4 о

Что же касается визуального осмотра Татищевым достопримечательностей Владимира (слой 5), то на этот счет сохранилось два его собственных ясных свидетельства. Первое содержится в письме Шумахеру от 12 сентября 1741 г. из Нижнего Новгорода: “Доношу вам, что я, едучи чрез Володимер, нарочно неколико времяни умедлил для осмотра древняго строения, [а именно соборной] церкви и башни, которое в примечании на гисторию древнюю внесу." 41

В частично опубликованном путевом дневнике Татищева сохранились коекакие подробности о его экскурсии. Во Владимир он прибыл 5 сентября, но достопримечательности в тот же день осматривать не стал. Зато 6 сентября:

по утру рано ходил тайный советник осматривать соборную церковь, строение в. кн. Андрея. Оная видно, что верх наделыван без гзымза; $;^{2}$ архитектура древняя; пилястры не по пропорции узки, и капители негде видны ордена тосканского, но сверх капителей аршина на полтора стена наделана, к ней же для утверждения стен приделаны быки из кирпича и камня. Внутри оная весьма тесна. В ней четыре столпа. Место княжеское видно, что делано новое. ${ }^{43}$

\footnotetext{
${ }^{40}$ Татищев 9, 278 (№ 184). (Tatishchev 9, 278, no. 184). Судя по академическим протоколам за конец 1740 и начало 1741 г., эту инициативу Татищева никто не обсуждал. В Академии среди коллекций рисунков, похоже, не было изображений исторических памятников, за исключением кое-каких видов окрестностей Петербурга. См. Протоколы заседаний Конференции Императорской Академии наук с 1725 по 1803 года, т. 1: 1725-1743 (Санкт-Петербург: Имп. Академия наук, 1897), 23637, 792. (Protokoly zasedanii Konferentsii Imperatorskoi Akademii nauk s 1725 po 1803 goda, t. 1: 1725-1743 (St. Petersburg: Imp. Akademiia nauk, 1897), 236-37, 792).

${ }^{41}$ Татищев 9, 281 (№ 194). (Tatishchev 9, 281, no. 194). Факсимиле письма см. на с. 282-83.

${ }^{42}$ Гзымз - карниз. См.: Словарь русского языка XVIII в., вып. 5 (Ленинград: Наука, Ленинградское отделение, 1989), 110. (Slovar' russkogo iazyka XVIII v., vyp. 5 (Leningrad: Nauka, Leningradskoe otdelenie, 1989), 110).

${ }^{43}$ Николай Н. Пальмов, “К астраханскому периоду жизни В. Н. Татищева," Известия Российской Академии наук - Bulletin de l'Académie des Science de Russie, серия 6, т. 19, вып. 6-8 (1925): 203. (Nikolai N. Pal'mov, "K astrakhanskomu periodu zhizni V. N. Tatishcheva," Izvestiia Rossiiskoi Akademii nauk - Bulletin de l'Académie des Science de Russie, seriia 6, t. 19, vyp. 6-8 (1925): 203)
} 


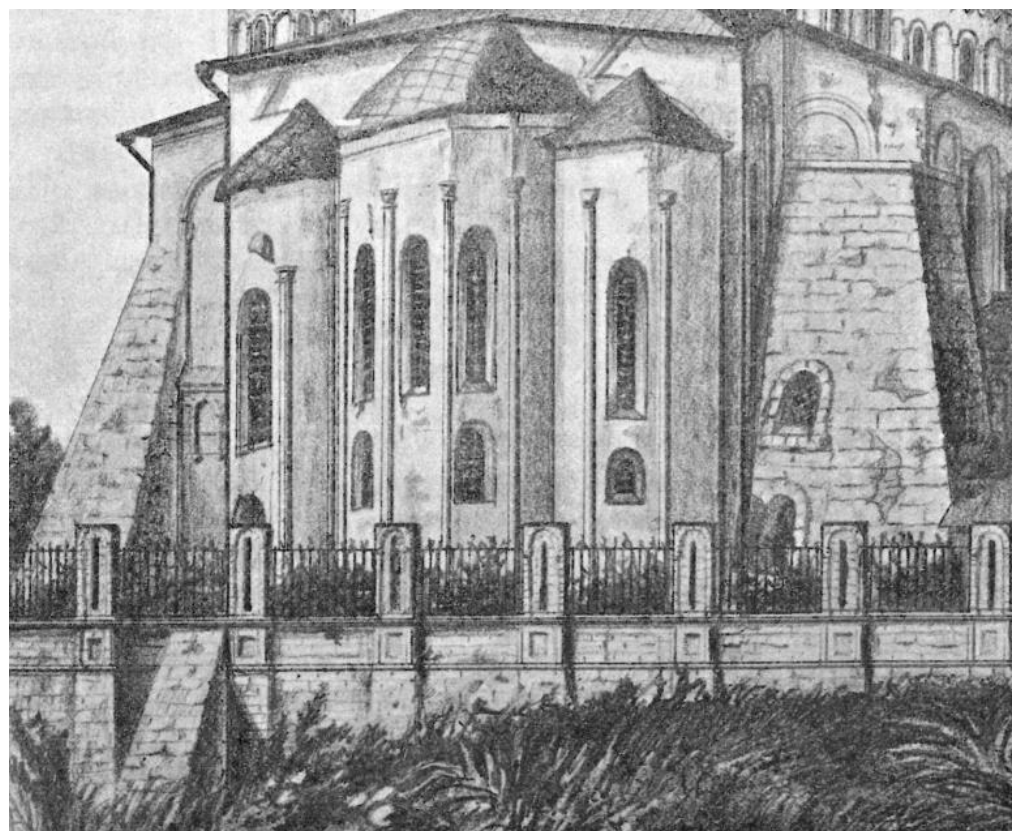

Иллюстрация 1. Успенский собор во Владимире до реставрации (фрагмент) ${ }^{44}$

Изображение Успенского собора до реставрации 1889-1891 гг. позволяет лучше понять описание Татищева. “Быками” он называет два контрфорса, пристроенных в 1708 г. по бокам собора. "Не по пропорции узкими пилястрами” с капителями “ордена тосканского” считает вертикальные тяги-полуколонки на апсидах. Согласно его витрувианско-палладианским представлениям, на капителях обязательно должен лежать антаблемент, а раз его нет, значит, стену “аршина на полтора” надстроили.

От Успенского собора Татищев пошел к Золотым воротам.

Ворота градские тако ж древнего строения из белого камня. Пилястры и капители - тосканские лучшею пропорциею, нежели у [соборной] церкви, токмо оная башня видно, что много на верху сломано было и после доделывано кирпичом.

Где на Золотых воротах Татищев мог увидеть архитектурные формы, которые он называет тосканскими пилястрами с капителями, притом “лучшею пропорциею”, чем у Успенского собора? Пожалуй, только на остатках надвратной церкви Ризоположения. Почему пропорции у “тосканских пилястров и капителей” здесь лучше, чем у собора, понятно: стены церкви ниже, отчего “пилястры” не столь ужасно вытянуты в высоту и не так тщедушны. Между тем свидетельство Татищева о наличии “пилястров с капителями" у церкви Ризоположения сходных с теми, что на восточном фасаде Успенского собора, должно было бы вызвать живейший интерес у историков архитектуры, - если бы оно им было известно. Ведь наблюдения Татищева можно истолковать в том смысле, что

\footnotetext{
${ }^{44}$ Александр И. Виноградов, История кафедрального Успенского собора в губ[ернском]. гор[оде]. Владимире, изд. 3 (Владимир: типо-литография губернского правления, 1905), между 58 и 59. (Aleksandr I. Vinogradov, Istoriia kafedral'nogo Uspenskogo sobora v gub[ernskom] gor[ode] Vladimire, izd. 3. (Vladimir: tipo-litografiia gubernskogo pravleniia, 1905), mezhdu 58 i 59).
} 
надвратную церковь строили уже точно новые мастера, а не старая артель Юрия Долгорукого, как порой, кажется, считают. ${ }^{45}$ Вот только на плане Н. фон Берка и А. Гусева 1779 г. - главном источнике сведений о надвратной церкви полуколонок, как на апсидах Успенского собора не обозначено. ${ }^{46}$ Успели бы они бесследно исчезнуть за те без малого 40 лет, что прошли с визита Татищева? В любом случае, судя по описанию, он видел все еще значительные фрагменты белокаменного храма, а не только результаты его перестройки из кирпича в 1536 или 1691-1695 гг. ${ }^{47}$

До сих пор в той церкви, про которую в “Примечании A” говорится, что она “некаким простым каменщиком перестроивана”, безусловно видели только что упомянутую надвратную церковь Ризоположения. ${ }^{8}$ При этом у читателя создавалось странное впечатление, будто Татищев то ли не оценил Успенский собор, то ли на пути к Золотым воротам вовсе его не приметил. Процитированные выше записи из путевого журнала, а также промежуточные редакции “Примечания A" позволяют усомниться в правильности общепринятого понимания его слов. Во-первых, мы убедились, что Татищев называл Успенский собор “соборной церковью” или же, краткости ради, просто “церковью”. Во-вторых, он исходил из того, что весь верх собора был надстроен (стена сверху “наделана”), так что “некакому простому каменщику” было где здесь оставить свой след. В-третьих, “церковь” из “Примечания А” “должна бы оным [либо “воротам градским”, либо же вообще “строениям” - M.Б.] преизяществовать.” Оценка, которая куда более подходит для главного городского собра, нежели для надвратной церкви. В-четвертых, история этой неназванной церкви описывается следующим образом: “как оная после перестроивана, потом от Батыя созжена и повреждена, а после починивана, то ея великолепия и того, чтоб с архитекторою согласовало, ничего не видно."49 Это Успенский собор был перестроен при Всеволоде, сожжен при штурме города в 1238 г., а позже восстановлен. ${ }^{50}$ Летописных свидетельств о сожжении Золотых ворот с церковью Ризоположения нет. Даже в город враги прорвались не через них, а сквозь пролом в стене неподалеку. ${ }^{51}$ Все говорит в пользу того, что внимание Татищева во Владимире было поделено между Золотыми воротами и Успенским собором.

\section{3. “Изящнейшая церковь” булгарского зодчего}

\footnotetext{
${ }^{45}$ Например: Тимофеева, Золотые ворота, 26 (Timofeeva, Zolotye vorota, 26.) Летописная дата освящения церкви Ризоположения - 1163 или 1164 г. - приходится на самый продуктивный период деятельности “новой” артели. См. Летопись по Лаврентиевскому списку, 334 (Letopis' po Lavrentievskomu spisku, 334); ПСРЛ, т. 9 (Санкт-Петербург: типография Э. Праца, 1862), 231. (PSRL, t. 9 (St. Petersburg: tipografiia E. Pratsa, 1862), 231).

${ }^{46}$ Воронин, Зодчество, 147. (Voronin, Zodchestvo, 147).

${ }^{47}$ Ни в одной реконструкции надвратного храма Золотых ворот (А. В. Столетов, Е. И. Дешалыт, С. В. Заграевский) не предусмотрено не только полуколонок, но и капителей.

${ }^{48}$ См., например: Воронин, Зодчество, 137. (Voronin, Zodchestvo, 137).

49 Татищев 4, 445. (Tatishchev 4, 445).

${ }^{50}$ См., например: “Татарове же много древіа наволочиша въ церковь и около церкви и зажгоша.” 109. ПСРЛ, т. 10, 109 (статья за 6745 г.). (PSRL, t. 10, 109 (stat'ia za 6745 g.).

51 “....] выбиша стену у Златыхъ вратъ [...]” Там же, 108. (Tam zhe, 108).
} 
Ни о Дмитриевском соборе, ни о других владимирских памятниках Татищев ничего не пишет. Хотя город в 1741 г. украшало больше зданий XII в., нежели сегодня, вряд ли Татищев смог бы их отличить от построек других времен. Как он определил, что архитектура Успенского собора “древняя", да и какой смысл вкладывал в само сочетание слов “архитектура древняя,” неизвестно. О ряде владимирских храмов Татищев не раз читал в летописях, но взглянуть на них, видимо, желания не испытывал. Он мог бы прикоснуться к остаткам деревянных стен и башен, возведенных, если верить тогдашним местным знатокам, еще при Всеволоде Большое Гнездо (они простоят на городских валах до 1750 г.). ${ }^{2}$ Однако тайный советник должен был поспешать по указу государя Иоанна Антоновича к новому месту службы и потому, бегло осмотрев Золотые ворота, “в 6-м часу поехал."

Хотя визит был и кратким, он принес плоды: Татищев обещал Шумахеру внести дополнение “в примечании на гисторию древнюю” после осмотра “древнего строения," “церкви и башни,” и обещание выполнил. Заодно мы узнаём, что Татищев временами досылал фон Эмме дополнения и поправки к примечаниям и что беловой список немецкого перевода никак не мог быть сделан ранее письма от 12 сентября 1741 г., в котором Татищев еще только обещал внести добавление в “Примечание А.” В реальности же готовая рукопись могла появиться вряд ли ранее, чем через пару месяцев - уже при царствовании императрицы Елизаветы.

Восстановленная хронология складывания немецкой версии "Примечания А," показывает, что первый его блок с оценкой “ворот градских" как “по тогдашнему времяни удивления достойных” (слой 3) не мог передавать собственные впечатления Татищева. Ему удастся рассмотреть и оценить ворота вместе с “церковью" только примерно полутора годами позже. Иными словами, ранее Татищева кто-то не просто рассмотрел Золотые ворота, но и выделил их из всего “оставшего строения" во Владимире как наиболее достойный внимания памятник. Мнение этого неизвестного эксперта было для Татищева столь авторитетным, что он, во-первых, сразу с ним согласился, во-вторых, воспроизвел его Шумахеру, заказывая составление и гравирование чертежей, и, в-третьих, при первой же возможности отправился сам разглядывать рекомендованные ему Золотые ворота.

Неизвестный информатор прямо сопоставлял Золотые ворота - в качестве лучше всего сохранившейся постройки времени Андрея Боголюбского - с храмом св. Георгия в Юрьеве-Польском как равноценным памятником времени Юрия Долгорукого. Если бы этот эксперт систематически читал летописи, ему было бы известно, что храм, возведенный артелью Юрия, быстро исчез: его разобрали уже при внуке заказчика. Татищев сначала этого тоже не знал - и потому включил неправильную датировку в свой комментарий, изначально целиком написанный, судя по всему, с чужих слов. Однако скоро историк в

\footnotetext{
$5^{2}$ Иван Ф. Дмитриевский, О начале Владимира что на Клязьме (Санкт-Петербург: Имп. Академия наук, 1802), 282. (Ivan F. Dmitrievskii, O nachale Vladimira chto na Kliaz'me (St. Petersburg: Imp. Akademiia nauk, 1802), 282); Николай Д. Дмитриевский, Взгляд на достопамятности Владимира (Москва: в типографии Лазаревых института Восточных языков, 1838), 20. (Nikolai D. Dmitrievskii, Vzgliad na dostopamiatnosti Vladimira (Moscow: v tipografii Lazarevykh instituta Vostochnykh iazykov, 1838), 20).
} 
хронологии разобрался, и потому заключительный “блок” (слой 6) в последующих версиях "Примечания A" больше не появится. Зато уже в Первой редакции основного текста Истории будет приведен верный пересказ летописного известия: “Князь Святослав Всеволодич, во крещении Гавриил нареченный, разруши церковь в Юрьеве, иж обетшала, юже созда дед его, и созда вновь чудну зело резаным камением." 53 Вероятно, Татищев узнал из летописи правильную датировку еще когда доделывал немецкий комментарий. Во всяком случае, в его немецкой рукописи имеется примечание (“Примечание В”), аналогичное тому, что и в Первой, и во Второй редакциях Истории Российской будет относиться к только что приведенному месту про снос старой церкви и возведение на ее месте новой: “Церковь эта стоит до сих пор, построена из белого камня и всюду украшена растительным орнаментом и фигурами, а над ними читается имя князя Святослава-Гавриила.” $* 54$

В последующих версиях “Примечание В” будет дважды дополняться. Сначала появится жалоба про надпись: “токмо разобрать все не без труда.” 55 Она означает, что легко прочитав имя князя и правильно его идентифицировав, Татищев испытывал понятные трудности с остальным содержанием пятистрочной надписи. ${ }^{56}$ Позже добавится неожиданно лестная общая оценка памятника, которая войдет и в печатное издание: “Сия есть по ея древности и особной архитектуре во всех руских строениях изящнейшая.”

Таблица 4. "Примечание B”

\begin{tabular}{|l|l|l|l|}
\hline $\begin{array}{l}\text { Обратный перевод } \\
\text { немецкого текст } \\
\text { примечаний }\end{array}$ & $\begin{array}{l}\text { Исходный } \\
\text { “Воронцовского } \\
\text { списка"58 }\end{array}$ & $\begin{array}{l}\text { Исправленный текст } \\
\text { “Воронцовского } \\
\text { списка” }\end{array}$ & Издание 1774 г. \\
\hline Прим. № 346 & Прим. № 488 & $\begin{array}{l}\text { Прим. № 523, } \\
\text { затем № 635 }\end{array}$ & Прим. № 635 \\
\hline
\end{tabular}

53 Татищев 4, 369. (Tatishchev 4, 369). См. то же место во Второй редакции: Татищев 3, 226. (Tatishchev 3, 226). Для сравнения: “Того же лета Святославъ князь въ Юргеве руші церковь святаго Юргя каменую, такоже бе обетшала и поламалася, юже бе создалъ дедъ его Юрги Володимеричь и святилъ великимъ священьем.” Летопись по Лаврентиевскому списку, 433. (Letopis' po Lavrentievskomu spisku, 433). Ср. в Львовской летописи, известной Татищеву: ПСРЛ, т. 20, ч. 1 (Санкт-Петербург: типография М. А. Александрова, 1910), 155. (PSRL, t. 20, part 1 (St. Petersburg: tipografiia M. A. Aleksandrova, 1910), 155).

54 "Diese Kirche stehet biß $\mathrm{DATO}_{2}$ ist von weis-/sen Steinen erbauet auch überall mit / Laub-Werck und FIGUREN gezieret, und / über solchen ist der Nahme des Fürsten / SWAETOSLAi GABriELIS zu lesen,” РГАДА, ф. 181, оп. 16, д. 1374, л. 2580б. (RGADA, f. 181, op. 16, d. 1374, 1. 258 ob.).

55 Татищев 4, 468. (Tatishchev 4, 468).

${ }^{56}$ Об этой надписи из пяти строк см.: Вольфганг В. Кавельмахер, “Краеугольный камень из лапидария Георгиевского собора в Юрьеве-Польском (к вопросу о так называемом Святославовом кресте),” в Древнерусское искусство. Русь. Византия. Балканы. ХІІІ век, отв. ред. Ольга Е. Этингоф (Санкт-Петербург: Дмитрий Буланин, 1997), 191-93 (Vol'fgang V. Kavel'macher, "Kraeugol'nyi kamen' iz lapidariia Georgievskogo sobora v Iur'eve-Pol'skom (k voprosu o tak nazyvaemom Sviatoslavovom kreste)," v Drevnerusskoe iskusstvo. Rus'. Vizantiia. Balkany. XIII vek, ed. Ol'ga E. Etingof (St. Petersburg: Dmitrii Bulanin, 1997), 191-93). Фотографию камня и надписи см. на c. 192.

57 Татищев 3, 269, 306. (Tatishchev 3, 269, 306).

$5^{8}$ Татищев 4, 468. (Tatishchev 4, 468).

59 Татищев 3, 269, 306. (Tatishchev 3, 269, 306). 


\begin{tabular}{|c|c|c|c|}
\hline $\begin{array}{l}\text { Церковь эта стоит до сих } \\
\text { пор, построена из белого } \\
\text { камня и всюду украшена } \\
\text { растительным орнаментом } \\
\text { и фигурами, а над ними } \\
\text { читается имя князя } \\
\text { Святослава-Гавриила. }\end{array}$ & $\begin{array}{l}\text { Церковь сия в Юрьеве } \\
\text { Польском доднесь стоит, } \\
\text { зделана из белого камени и } \\
\text { вся резана, на которой имя } \\
\text { князя Святослава Гавриила } \\
\text { и год подписано, токмо } \\
\text { разобрать все не без труда. }\end{array}$ & $\begin{array}{l}\text { Церковь сия в Юрьеве } \\
\text { Польском доднесь стоит, } \\
\text { сделана из белаго камени и } \\
\text { вся резана, на которой имя } \\
\text { князя Святослава Гавриила, } \\
\text { и год подписано, токмо все } \\
\text { разобрать не без труда. Сия } \\
\text { есть по ея древности и } \\
\text { особной архитектуре во всех } \\
\text { руских строениях } \\
\text { изящнейшая. }\end{array}$ & $\begin{array}{l}\text { Церковь сия в Юрьеве } \\
\text { Польском доднесь стоит, } \\
\text { сделана из белаго камени и } \\
\text { вся резана, на которой имя } \\
\text { князя Святослава Гавриила, } \\
\text { и той подписи разобрать не } \\
\text { без труда. Сия есть по ея } \\
\text { древности и особной } \\
\text { архитектуре во всех Руских } \\
\text { строениях изящнейшая. }\end{array}$ \\
\hline
\end{tabular}

Утверждать категорически, что Татищев никогда (или по меньшей мере никогда ранее 1739 г.) не бывал в Юрьеве-Польском, было бы при нынешних неполных сведениях о его итинерарии слишком смело. Лучше сформулировать осторожно: поскольку известий о визите Татищева в этот город, лежавший в стороне от его основных маршрутов, обнаружить не удалось, резонно допустить, что Татищев вряд ли посещал Юрьев-Польской. Если это допущение подтвердится, то окажется, что и в данном случае он следовал за чужим, но авторитетным мнением. Однако, судя по тому, что Татищев, видимо, продолжительное время работал над расшифровкой надписи, в его распоряжении была ее зарисовка, а не только ее описание. Возможно, о "растительном орнаменте и фигурах," как и вообще об изяществе “особной архитектуры” храма Татищев судил тоже не столько по рассказам, сколько по чьим-то рисункам. ${ }^{61}$

Пускай мысль сопоставлять Золотые ворота с Георгиевским собором Татищеву и не принадлежит, но именно он повернул ее в новую сторону, добавив от себя столь же безапелляционное суждение, как и в случае с “архитектом Барбароссы”: “Мастер был болгарский." утверждение, что зодчий прибыл из Волжской Булгарии, присутствует в обеих редакциях Истории Российской. ${ }^{63}$ Однако было ли оно сформулировано уже ко времени написания немецкого “Примечания В,” остается лишь догадываться. Сообщение Тверской летописи, что создателем храма якобы выступал сам князь Святослав Всеволодович, Татищев либо не знал, либо его проигнорировал. ${ }^{64}$ Для него возведение нового храма в Юрьеве стало прямым следствием победы Святослава над булгарами: “А Святослав иде во град свой Юрьев и от имения болгарского нача в Юрьеве строить церковь каменну святого Георгиа." 65 Отсюда Татищеву легко было сделать и следующее допущение, что среди булгарских пленных или заложников мог оказаться и зодчий. Особенно если счесть узоры,

\footnotetext{
${ }^{60}$ Татищев, История, 526. (Tatishchev, Istoriia, 526).

${ }^{61}$ Вообще-то храм был восстановлен из руин в 1471 г. при полном искажении его исходных пропорций.

${ }_{62}^{62}$ Татищев 3, 226. (Tatishchev 3, 226).

${ }^{63}$ См. в Первой редакции: “А мастер болгорский строи ю”. Татищев 4, 369. (Tatishchev 4, 369).

64 “И създа ю Святославъ чюдну, резанымъ каменемъ, а самъ бе мастеръ”. ПСРЛ, т. 15 (СанктПетербург: в типографии Л. Демиса, 1863), 355. (PSRL, t. 15 (St. Petersburg: v tipografii L. Demisa, 1863), 355).

${ }^{65}$ Татищев 4, 358. (Tatishchev 4, 358). Во Второй редакции: “Святослав пришед во град свой Юриев и от имения болгарского начал строить церковь святого Георгиа каменную”. Татищев 3, 209. (Tatishchev 3, 209).
} 
покрывающие стены юрьевского храма, “восточными”, похожими на те, что возможно, встречались в развалинах городов Волжской Булгарии.

\section{4. От “Примечания Б” - к примечанию-призраку}

Вернемся, наконец, к “Примечанию Б” в немецкой версии. Оно дает не так мало, как может показаться на первый взгляд: “Около того времени правил император Фридерикус Барбаросса, а после него его сын Генрикус VI. Но далее ниже будет указано, что от этого императора были отправлены посланцы ко Всеволоду." *66

Во-первых, написание имен наводит на мысль. что Татищев здесь заглядывал в какой-то латинский справочник, чтобы выяснить, какой император правил в 1190 г. Во-вторых, видно, что ошибка с номером Генриха в издании Истории Российской на совести безымянного типографа и редактора Миллера, но не автора. В-третьих, здесь так же, как и в немецком “Примечании А,” нет ни слова про архитектора Фридриха I. Однако, в-четвертых, сообщается о посланцах к Всеволоду. Хотя при данной формулировке можно гадать, который из двух императоров их отправил, нам уже известно, что подразумевается Генрих VI. (Иначе непонятно, зачем его вообще было упоминать.) Наконец, в-пятых, отсылка делается, в отличие от изданной версии, не к предшествовашему “Примечанию А," а к какому-то месту “далее ниже” (weiter herunter).

Раз Татищев упоминает императорских посланцев ко Всеволоду, значит, он должен был уже познакомиться с тем гипотетическим источником, в котором пересказывалась присланная во Владимир грамота Генриха VI про “дружбу” и “архитекта”. Выходит, Татищев по каким-то причинам счел за лучшее скрыть от немецких академиков свою находку, вычеркнув упоминание о ней из обоих примечаний “А” и “Б.” Задаваемый им в “Примечании А” риторический вопрос, откуда князь Андрей мог взять столь хорошего архитектора (слой 2), служит лишь прикрытием: он заменил исходное утверждение, которое должно было стоять на этом месте еще до начала работы над переводом, и которое вернется во все последующие русские версии тех же примечаний, - утверждение, что зодчего отправил Фридрих I.

Иными словами, русский прототекст “Примечания А” к концу 1739 г., перед тем как Татищев цензурировал его, отправляя переводчику, должен был выглядеть приблизительно следующим образом:

Сие примечание достойно, что Андрей имел архитекта по дружбе от императора Фридерика Барбароссы, и видимо, что архитект был искусной, ибо оставшие его строения, а наипаче ворота градские, по тогдашнему времяни удивления достойны. Точно так же и церковь, выстроенная в Юрьеве-Польском его отцом, достойна внимания и восхищения. (Последнее предложение - в обратном переводе с немецкого).

\footnotetext{
66 "Umb diese Zeit REGIERTe Kayser FrIEDERI-/CUS BARBAROSSA und nach ihm sein / Sohn HENRICUS VI. Weiter herunter / aber wird angezeiget, daß vom Kayser / Gesandten an WsEWOLOD geschickt gewe/sen”. РГАДА, ф. 181, оп. 16, д. 1374, л. 245. (RGADA, f. 181, op. 16, d. 1374, l. 245).
} 
Логика этого фрагмента понятна: хотя “архитект Барбароссы,” построивший Золотые ворота, и не имел отношения к юрьевскому храму, оба сохранившихся здания и сегодня производят равно сильное впечатление.

Не менее существенно обещание автора, что “ниже” он расскажет о посольстве от Генриха VI к Всеволоду, а значит, надо полагать, и о грамоте, привезенной посланниками, в которой упоминалось об “архитекте.” Однако это ключевое “Примечание Г” отсутствует! Тем не менее, ссылка на него дается не только в немецкой рукописи, но и в обоих вариантах “Примечания Б” из “Воронцовского списка": “А ниже показуется, что послы ко Всеволоду от цесаря были." только в беловом варианте Второй редакции отсылка к примечанию ниже будет заменена нелогичной ссылкой на “Примечание А" выше, в котором никаких пояснений про доверенных лиц Генриха VI не содержалось. ${ }^{68}$ Так грубо нарушить собственные обещания автора обычно вынуждают внешние обстоятельства. Странное поведение Татищева проще всего объяснить тем, что нужная выписка из источника потерялась, но автор, никак не желая отказываться от “архитекта Барбароссы," всё пытался разыскать ее вновь. Когда же последние надежды угасли, он пошел на уловку, “закольцевав” примечания “А” и “Б."

Возможное возражение, что “ниже” могло означать ссылку не на примечание, а на какое-то место в основном тексте, отвести несложно. Блок текста с похвалой “архитекту" Барбароссы в первом варианте "Воронцовского списка" помещен в самом начале “Примечания A," а в последнем - напротив, в самом его конце. Тем не менее, в обоих случаях автор ставит после него “н.” (т.е “нота” или “нотица”), как он всегда делает, отсылая именно к примечаниям. В первом случае он дает ошибочный номер 382, во втором же не приводит никакого. ${ }^{69}$ Иными словами, автор все время планирует вставить “Примечание Г, ” но так этого и не делает.

Можно ли определить, к какому разделу основного текста (а значит, и к какому году) относилось пропавшее примечание? Очевидно, что появиться оно должно было, скорее всего, при описании либо успешного правления Всеволода (почтение которому спешат выразить чужие государи), либо же какого-либо заметного строительства во Владимире - причем только между 1190 (“Примечание Б”) и 1197 (кончина Генриха VI) годами. В соответствующей главе 23 [32] много страниц посвящено событиям новгородским, киевским, рязанским, смоленским, галицким... Несколько упоминаний Всеволода относится к пространным “сюжетным” повествованиям о распрях, вставлять в которые сообщение об иностранном посольстве было бы совсем некстати. В результате поисков более или менее подходящих мест обнаруживается пять. Все они относятся к делам строительным.

\section{Таблица 5. “Владимирские” сюжеты за 1190-1197 гг. в главе 23 [32]}

\footnotetext{
${ }^{67}$ Татищев 3, 302 (Tatishchev 3, 302); Татищев 4, 454 (Tatishchev 4, 454). Эта фраза, видимо, без изменений перенесена из ранних вариантов, так что фон Эмме скорее всего перевел именно ее, когда написал: "Weiter herunter aber wird angezeiget."

${ }^{68}$ Татищев 3, 253. (Tatishchev 3, 253).

69 "Сие примечание достойно, что Андрей имел архитекта по дружбе от императора Фридерика Барбароссы, как н. 382 [...].” Татищев 4, 444. (Tatishchev 4, 444). “Мастеры же [...] присланы были от императора Фридерика Барбароссы, с которым Андрей дружбу имел. Зри н. ...” Татищев 3, 295. (Tatishchev 3, 295).
} 
Первой редакции

\begin{tabular}{|l|c|l|}
\hline & \multicolumn{1}{|c|}{ год } & \multicolumn{1}{|c|}{ событие } \\
\hline 6699 (1191) & $\begin{array}{l}\text { Князь великий Всеволод заложи град новый в Суздали, и того ж лета } \\
\text { срублен бысть. }\end{array}$ \\
\hline 6700 (1192) & $\begin{array}{l}\text { Того ж году октября 25 дня у князя Всеволода родися сын [...] И тогда } \\
\text { же заложи великий князь Всеволод в Володимери церковь Рожества } \\
\text { пресвятыя богородицы каменну. }\end{array}$ \\
\hline 6701 (1193) & $\begin{array}{l}\text { Того ж году августа месяца обнови Всеволод в Суздали церковь } \\
\text { святыя Богородицы, ея же палася половина безрядьем, и покрыта ю } \\
\text { оловом. }\end{array}$ \\
\hline 6703 (1195) & \begin{tabular}{l} 
В Володимере заложен бысть сего году детинец (замок) иуния 4-го \\
дня. Того ж году обновлена церковь святыя Богородицы златоверхия \\
епископом Иоанном, иж погоре в великий пожар, и бысть устроена, \\
аки нова. \\
нового Того жоду в Переяславли у Клещина озера срубиша град \\
\hline 6703 (1195)
\end{tabular} & $\begin{array}{l}\text { Того ж лета епископ Иоан заложи во Владимире на воротех церковь } \\
\text { каменну Зачатия святыя богородицы месяца майя в зо день. }\end{array}$ \\
\hline
\end{tabular}

Из получившегося перечня наибольшее отношение к “архитекту Барбароссы" имело “обновление” Успенского собора. ${ }^{72}$ Конечно, настораживает упоминание надвратной церкви, но будем исходить из допущения, что Татищев умел различить между старыми городскими воротами - Золотыми с церковью Ризоположения - и новыми воротами детинца с церковью Иоакима и Анны. В любом случае, наиболее подходящим местом для добавления “Примечания Г” представляются страницы, посвященные событиям 1195 г.

\section{5. Польза от Фридриха Барбароссы}

Об “архитекте” Барбароссы Татищев писал не только в своем главном труде. По всей видимости, еще в 1744 г. он закончил работу, которая лишь в 1793 г. выйдет из печати под названием “Лексикон российской исторической, географической, политической и гражданской.” ${ }^{73} \mathrm{~B}$ ней Татищев, помимо

$7^{70}$ Ср.: “Того же лета заложи благоверный князь Всеволодъ Юргевичь детинець, в граде Володимери, месяца июня въ 4 день [...]. Того же лета, месяца августа, обновлена бысть церкы святое Богородици Володимери, аже бе ополела в великий пожаръ, блаженнымъ епископомь Иваномъ [...] и бысть опять акы нова [...]” Летопись по Лаврентиевскому списку, 390 (Letopis' po Lavrentievskomu spisku, 390), про основание Переяславской крепости см. на с. 391. Не всё в кратком сообщении Татищева можно вывести из точно известной ему Никоновской летописи. Ср.: ПСРЛ, т. 10, 21-22. (PSRL, t. 10, 21-22).

${ }^{71}$ Ср.: “В том же лете заложи блаженыи епископъ Иоанъ, на воротех святе Богородици церковь камену во имя Зачатье святыа Богородица, месяца маия въ 30 день [...].” ПСРЛ, т. 38, 158. (PSRL, t. $38,158)$.

$7^{2}$ Татищев, очевидно, не знал, что внешний вид осмотренного им храма сложился не при князе Андрее, как было записано в его путевом журнале, а как раз в результате перестройки, предпринятой Всеволодом - правда, еще после пожара 1185 г. Ущерб от нового пожара десять лет спустя, о котором здесь идет речь, был сравнительно невелик.

73 Сигизмунд Н. Валк, “О составе издания,” в Татищев 8, 30-31. (Sigizmund N. Valk, “O sostave izdaniia,” v Tatishchev 8, 30-31). В июле 1745 г. автор отослал первую половину этого труда в 
прочего, поделился собственными впечатлениями от экскурсии трехлетней давности:

Андрей Боголюбский, учиняся великим князем, в 1157 году престол из Ростова во Владимер перенес и, получа архитекта от императора Фридерика Барбороссы, церковь соборную и врата градские построил, которые доднесь хотя чрез раззорение многое лепоты их утратили, однако ж еще видения достойны. ${ }^{74}$

Упоминание “зодчего Барбароссы” в “Лексиконе” оказывается самым ранним из достоверно известных сегодня у Татищева, ведь приведенная выше реконструкция “Примечания A” 1739 г. является гипотетической. И эта же запись окончательно разъясняет, о какой владимирской “церкви” пишет Татищев в том же самом контексте во всех сходных местах - не о надвратной, а о “соборной.”

Жаль, что “Лексикон” был доведен Татищевым только до буквы “Л”: хотелось бы прочитать и его статью про Юрьев-Польской. Ведь в Гистории создатели Золотых ворот во Владимире и храма в Юрьеве поставлены на одну доску. Между ними существует своего рода симметрия, которую Татищев ясно выразил в “Росписи алфабетической" к Первой редакции Гистории короткой записью: “Архитекты в Руси: из Немец н. 341, 403; из Болгор н. 488." 75 Если для сегодняшних историков архитектуры Георгиевский храм - это последнее создание школы, основанной в 1158 г. мастерами Андрея Боголюбского, то в глазах Татищева он предстает “болгарской” альтернативой архитектуре “немецкого” зодчего.

Последнее слово по интересующему нас вопросу было сказано Татищевым за два года до смерти в “Представлении о купечестве и ремеслах." ${ }^{76}$ Автор, “видя себя при конце жизни,” но все еще желая приносить пользу, в письме от 12 мая 1748 г. просит М.И. Воронцова (1714-1767) передать эту записку государыне. ${ }^{77}$

В самом начале “Представления" Татищев дает историческое обоснование своему тезису, что “весьма давно государи о пользе купечества руского прилежали.” Заботу о купечестве он усматривает уже в “договорех с императоры греческими” Олега, Игоря и Святослава, переходя затем к заслугам на том же поприще других правителей - от Ярослава до Алексея Михайловича, - чтобы

Академию и больше уже к нему не возвращался. См.: Татищев 9, 315 (№ 223). (Tatishchev 9, 315, no. 223).

${ }^{74}$ Василий Н. Татищев, “Лексикон Российский исторической, географической, политической и гражданской,” в Татищев 8, 213. (Vasilii N. Tatishchev, "Leksikon Rossiiskii istoricheskoi, geograficheskoi, politicheskoi i grazhdanskoi,” v Tatishchev 8, 213). См. статью “Владимер Белорусский и Володимер”.

75 Татищев 4, 534. (Tatishchev 4, 534).

${ }^{76}$ Подробнее см.: Николай Л. Рубинштейн, “Неизвестная записка В. Н. Татищева “Представление о купечестве и ремеслах в России," Доклады и сообщения Исторического факультета МГУ, вып. 8 (Москва: МГУ, 1949), 39-47. (Nikolai L. Rubinshtein, "Neizvestnaia zapiska V. N. Tatishcheva "Predstavlenie o kupechestve i remëslakh v Rossii,"” Doklady i soobshcheniia Istoricheskogo fakul'teta $M G U$, vyp. 8 (Moscow: MGU, 1949) 39-47). Первую публикацию см. в: Исторический архив 7 (1951): 410-26. (Istoricheskii arkhiv 7 (1951): 410-26). Переиздание: Василий Н. Татищев, “Представление о купечестве и ремеслах," в Татищев 8, 392-401. (Vasilii N. Tatishchev, "Predstavlenie o kupechestve i remëslakh," v Tatishchev $8,392-401)$.

77 Татищев 9, 340 (№ 248). (Tatishchev 9, 340, no. 248). 
подвести читателя к “мудрым учреждениям” Петра Великого, а главное, к тому, что государыня Елисавет Петровна “все законы, уставы и учреждения родителя ея повелела возобновить и в сусчее действо произвести.”

В историческую цепочку радетелей о купечестве оказался вставлен и "Юрий, или Георгий, II, великий князь в Белой Руси,” строивший многие грады, куда он разных иностранцев приглашал.

Сын его Андрей I Боголюбский по союзу с императором Фридериком Барбароссою и с болгары волскими многих ремесленников призвал, междо которыми, видно, были искусные архитекты, как строения оставшия во Владимире церкви и ворот градских и в Юрьеве церковь видения достойные свидетельствуют. ${ }^{7}$

Итак, симметрия между владимирскими Золотыми воротами и юрьевским собором, обозначившаяся еще в исходном варианте “немецких примечаний” 1739 г., проведенная в письме Шумахеру в ноябре 1740 г., переросшая в симметрию между “немцами” и “болгарами” в “Росписи алфабетической” Первой редакции, дозрела теперь до полного совершенства. Правда, ради такой симметрии давнюю “дружбу” Андрея Боголюбского с Фридрихом Барбороссой пришлось снизить до “союза" между ними - такого же, как у Андрея с болгарами. Зато вместо одного “достаточного архитекта" возникло сразу как минимум двое, не считая сопровождавших их “многих ремесленников". Ради все той же симметрии Татищев забывает приведенную в его собственной Истории правильную датировку юрьевского собора и относит его ко времени Андрея Боголюбского, которого в ряду других перечисленных в записке правителей Руси стилизует под Петра I.

Не стоит искать других идеологических целей, ради которых Татищеву стоило бы привлекать фигуру Фридриха I Барбароссы. Менее всего она годилась для возвеличивания своей “дружбой” владимирского князя. Татищев представлял Фридриха I вовсе не как великого и грозного императора. Во-первых, Татищев вчитывался в рассказ польского историка Мартина Кромера (1512-1589) о походе Штауфена в Польшу. ${ }^{79}$ Во-вторых, он знал, что император умер, возглавляя Крестовый поход. ${ }^{80}$ Но главное, с чем у Татищева связывался Фридрих I, это, втретьих, многовековой конфликт между императорами и римскими папами. Татищев не жалеет злых слов в адрес понтификов (как и в адрес их "русского аналога” - патриарха Никона).

\footnotetext{
$7^{8}$ Татищев, “Представление,” 393. (Tatishchev, “Predstavlenie,” 393).

79 Татищев, похоже, путался в том, на чьей стороне оказались русские князья. В немецком комментарии они действуют на стороне императора: "In diesem Jahre sagt CROMERUS habe / Kayser Friedericus einen Zug nach / POHLEN gethan, wobey ihm die Rußische[n] / Fürsten ASSISTIRet, wovon nebst / vielen andern in Roth-Reußen / vorgefallenen // vorgefallenen Ergebenheiten in denen Rußischen ANNALIBUS dahero nichts / enthalten, weil sich der Orthen keine ScRIBENTen gefunden”. РГАДА, ф. 181, оп. 16, д. 1374, л. 229-2290б. (RGADA, f. 181, op. 16, d. 1374, 1. 229-229 оb.). Сходно: Татищев 3, 294 (Tatishchev 3, 294); Татищев 4, 444 (Tatishchev 4, 444). Напротив, русские помогают полякам против Фридриха: Татищев 2, 268 (Tatishchev 2, 268); Татищев 4, 437 (Tatishchev 4, 437).

8 татищев 3, 254 (Tatishchev 3, 254); Татищев 4, 454 (Tatishchev 4, 454).
} 
Довольно всем известно, что римские архиепископы дерзнули власть над государи и народы требовать, с государи нечестивым образом поступать, народ от учиненной государем присяги увольнять, на них возмущать и престола лишать, как нас истории о Фридерике первом и Генриках во ужас приводят. ${ }^{81}$

В другом варианте той же сентенции Татищев упоминает унижение, якобы испытанное Фридрихом I в Венеции в 1177 г. в сцене примирения с папой Александром III. Как утверждали впоследствии пропапские хронисты, понтифик будто бы наступил на склонившегося поцеловать его ноги императора. Осуждая пап, Татищев поставил венецианский эпизод в один ряд с покаянием Генриха IV в Каноссе. По его словам, папы

чрез слепое народа к ним послушание государей с престола свергали, подданных от рабства и послушания присяги их разрешали, не токмо рабов противо государя, но детей противо родителей и государей своих воевать понуждали, цесарю на шею ногою становились или у дверей босо и без одежды просить прощения принуждали, как то читаем о цесарях Фридерике Барбароссе и Гендрике. ${ }^{82}$

Несложно понять, откуда у Татищева именно такие сведения о Фридрихе I: он воспроизводит общие места протестантской публицистики, со времен Лютера клеймившей пап за их глумление над германскими государями. Трудно представить, чем такой - лютеранский - Фридрих Барбаросса мог оказаться полезен владимирским князьям.

\section{6. Степенные книги, известные и потерянные}

В одной из промежуточных версий “Примечания А," отразившихся в "Воронцовском списке," Татищев прямо называет источник своего знания о зодчем Барбароссы: "Мастеры же, по Степенной, присланы были от императора Фридерика Барбароссы." ${ }^{83}$ Как убедительно показано в недавних исследованиях, отсылки Татищева к его источникам не отличаются точностью. ${ }^{84}$ Если он и не мистифицировал читателей сознательно, то, видимо, и не заботился особенно об аккуратности своих ссылок - так, как это принято у историков сегодня. Он указывал дополнительные сведения в спешке или по памяти, а она его нередко

\footnotetext{
${ }^{81}$ Татищев 1, 379. (Tatishchev 1, 379). Под “Генриками” здесь подразумеваются Генрих IV, вынужденный к публичному покаянию в Каноссе, и Генрих VII (ок. 1275-1313), якобы отравленный папским агентом.

${ }^{82}$ Василий Н. Татищев, “Разговор дву приятелей о пользе науки и училищах,” в Татищев $8,80-81$. (Vasilii N. Tatishchev, "Razgovor dvu priiatelei o pol'ze nauki i uchilishchakh," v Tatishchev 8, 80-81).

${ }^{83}$ Татищев 3, 295. (Tatishchev 3, 295).

${ }^{84}$ См. многочисленные примеры сомнительных ссылок у Татищева в работах: Алексей П. Толочко, "История российская" Василия Татищева: источники и известия (Москва: Новое литературное обозрение; Киев: Критика, 2005). (Aleksei P. Tolochko, "Istoriia rossiiskaia" Vasiliia Tatishcheva: istochniki i izvestiia (Moscow: Novoe literaturnoe obozrenie; Kiev: Kritika, 2005); Горовенко, Василий Татищев (Gorovenko, Vasilii Tatishchev).
} 
подводила. Один и тот же источник он мог называть совершенно по-разному. Тем не менее, игнорировать его собственное указание без проверки не стоит.

Степенная книга представляет собой историческую компиляцию 6о-х гг. XVI в. получившую широкое распространение во множестве вариантов, возникавших не только в XVI и XVII вв., но еще и в начале XVIII в. ${ }^{85}$ K настоящему времени известно 145 ее списков. ${ }^{86}$ Сведения, полученные из Степенных книг, Татищев обещал приводить, в отличие от летописных свидетельств, только в примечаниях, что к нашему случаю вполне подходит. ${ }^{87}$ Разумеется, в исходном тексте Степенной книги, недавно переизданной в соответствии со всеми академическими канонами, нет ни слова о послании Генриха VI к Всеволоду. ${ }^{8}$ Однако было бы непредусмотрительно заведомо исключать саму возможность того, что в каком-то из многочисленных поздних манускриптов могла встретиться фраза, вдохновившая Татищева на его утверждение. Собственного экземпляра Степенной книги у Татищева, судя по всему, не имелось, но зато он сумел познакомиться с разными ее рукописями, включая и ту, что обнаружил в университетской библиотеке в Уппсале. ${ }^{89}$ Татищев и сам копировал интересовавшие его места из попадавшихся ему списков, и получал уже готовые цитаты от своих “снискательных к гистории русской” приятелей. Коллекция выписок из Степенной книги упоминается в посмертной описи библиотеки Татищева. ${ }^{90}$ На Степенную книгу Еропкина Татищев прямо ссылается в обеих редакциях Истории в примечании к рассказу об убиении Андрея Боголюбского. ${ }^{91}$ Вероятно, тот же памятник подразумевается во Второй редакции под “манускриптом Еропкина" в рассказе о казни вдовы Андрея, якобы замешанной в заговоре. ${ }^{92}$ Сохранились выписки Татищева о событиях второй половины XV-XVII вв. из Степенных книг, принадлежавших В. А. Урусову (ок.

\footnotetext{
${ }^{85}$ Подробно см.: Алексей В. Сиренов, Степенная книга: история текста, Москва: Языки славянских культур, 2007 (Aleksei V. Sirenov, Stepennaia kniga: Istoriia teksta, (Moscow: Iazyki slavianskikh kul'tur, 2007); Сиренов, Степенная книга и русская историческая мысль XVI-XVIII вв., Москва-Санкт-Петербург: Альянс-Архео, 2010. (Sirenov, Stepennaia kniga i russkaia istoricheskaia mysl' XVI-XVIII vv. (Moscow-St. Petersburg: Al'ians-Arkheo, 2010)). Татищев полагал, что Степенную книгу составили еще на рубеже XIV и XV вв., а в XVI в. только дополнили.

${ }^{86}$ Степенная книга царского родословия по древнейшим спискам. Тексты и комментарий в трех томах, отв. ред. Николай Н. Покровский, Гейл Д. Ленхофф, т. 1 (Москва: Языки славянских культур, 2007), 26. (Stepennaia kniga tsarskogo rodosloviia po drevneishim spiskam. Teksty $i$ kommentarii v trekh tomakh, otv. red. Nikolai N. Pokrovskii, Geil D. Lenhoff, t. 1 (Moscow: Iazyki slavianskikh kul'tur, 2007), 26).

87 “Затем степенные, хронографы, четьи минеи, прологи и пр. хотя много помоществовали, но из них в примечании токмо для изъяснения вношено, а в текст не мешано [...]." Татищев 4, 49. (Tatishchev 4, 49). Сходно во Второй редакции: Татищев 1, 91. (Tatishchev 1, 91).

${ }^{88}$ Степенная книга царского родословия, 448-82. (Stepennaia kniga tsarskogo rodosloviia, 448-82). (Степень VI).

${ }^{89}$ Сиренов, Степенная книга: история текста, 10. (Sirenov, Stepennaia kniga: Istoriia teksta, 10).

${ }^{90}$ Пекарский, Новые известия, 59. (Pekarskii, Novye izvestiia, 59). "Из Степенной выписки."

${ }^{91}$ Татищев 3, 249. (Tatishchev 3, 249); Татищев 4, 449 (Tatishchev 4, 449). Мнение, что никакого “манускрипта Еропкина" не существовало, см. в: Толочко, “История российская" Василия Татищева, 180-85. (Tolochko, "Istoriia rossiiskaia" Vasiliia Tatishcheva, 180-85). Напротив, о реальности Степенной книги Еропкина см.: Сиренов, Степенная книга: история текста, 315. (Sirenov, Stepennaia kniga: Istoriia teksta, 315).

${ }_{92}^{2}$ Татищев 3, 113, 250, примеч. 520. (Tatishchev 3, 113, 250, note 520).
} 
1690-1741) и Волынскому. ${ }^{93}$ При этом А. В. Сиренов допускает, что “списки Еропкина и Волынского или являются одной рукописью, перешедшей от одного владельца к другому, или связаны единством происхождения..." 94 Считается, что Степенная книга Волынского пропала: возможно, сгорела в 1812 г. ${ }^{95} \mathrm{~B}$ его же собрании имелись некие выписки из Степенной книги (которую какой-то архивист впоследствии определил как “Ростовский летописец,”) датированные 1716 г. и представлявшие собой, видимо, самостоятельную переработку какого-то варианта исходного текста. ${ }^{96}$ Благополучно идентифицирован экземпляр Cтепенной книги из собрания А. Ф. Хрущова. ${ }^{97}$ Согласно оценке Сиренова, использованные Татищевым манускрипты Урусова, Еропкина и Волынского (если последние два представляли собой все же разные рукописи) относились к семейству Латухинской Степенной, составленной архимандритом Желтоводского монастыря Тихоном Макарьевским в 1676 г. ${ }^{88}$ Никаких упоминаний Фридриха I Барбароссы или же Генриха VI в рукописях Степенной книги пока что выявлено не было. Однако поиск среди манускриптов из собраний Волынского, Хрущова и Еропкина, еще в XVIII в. оказавшихся в конце концов в московском Архиве коллегии иностранных дел, имеет смысл продолжить. ${ }^{99}$

${ }^{93}$ Александр Х. Востоков, Описание русских и словенских рукописей Румянцевского музеума (Санкт-Петербург: Имп. Академия наук, 1842), 646-48 (№ 416). (Aleksandr H. Vostokov, Opisanie russkikh i slovenskikh rukopisei Rumiantsevskogo muzeuma (St. Petersburg: Imp. Akademiia nauk, 1842, 646-48, nо. 416)). Оригинал: Российская государственная библиотека, ф. 256, № 416, л. 1-251 (Rossiiskaia gosudarstvennaia biblioteka, f. 256, no. 416, 1. 1-251) (Степенная Урусова); л. 252-79 (1. 252-79) (Степенная Волынского). Согласно Сиренову, для части, относящейся к Степенной Урусова, имеется более ранний список: РГАДА, ф. 199, Портфели Миллера, оп. 1, № 46/6. (RGADA, f. 199, Portfeli Millera, op. 1, no. 46/6). Сиренов, Степенная книга: история текста, 315. (Sirenov, Stepennaia kniga: Istoriia teksta, 315). Судя по архивной машинописной описи фонда 199, дела № 46/7 и 46/8 могут представлять собой выписки оттуда же. Они охватывают в общей сложности время от Ивана III до Алексея Михайловича. РГАДА, ф. 199, оп. 1, л. 4об. (RGADA, f. 199, op. 1, 1. 4 $\mathrm{ob})$.

${ }^{94}$ Сиренов, Степенная книга: история текста, 315-16. (Sirenov, Stepennaia kniga: Istoriia teksta, 315-16).

${ }^{95}$ Толочко, “История российская" Василия Татищева, 176. (Tolochko, "Istoriia rossiiskaia” Vasiliia Tatishcheva, 176); Сиренов, Степенная книга: история текста, 316. (Sirenov, Stepennaia kniga: Istoriia teksta, 316).

${ }_{96}^{6}$ РГАДА, ф. 181, оп. 1, № 19/24. (RGADA, f. 181, op. 1, no. 19/24). См. рукописную архивную опись фонда: “Это после Степенной книги первый опыт Прагматической Русской Истории, составлен Государственной Коллегии Иностранных дел Секретарем Иваном Юрьевым, доведен до 1564 г. [...] Из дел Архива видно, что сия книга поступила [в] оный в числе двух экземпляров из пожитков А. Волынского [...] 1746 году Марта 10-го беловой экземпляр [отослан] в Санктпетербург в Коллегию, а этот черновой остался в Архиве." РГАДА, ф. 181, оп. 1, л. 1020б.-10зоб. (RGADA, f. 181, op. 1, l. 102v103 ob.).

${ }^{97}$ РГАДА, ф. 181, оп. 1, № 26/34. (RGADA, f. 181, op. 1, no. 26/34).

98 Латухинская Степенная книга. 1676 г., издание подготовили Николай Н. Покровский, Алексей В. Сиренов, отв. ред. Николай Н. Покровский, (Москва: Языки славянской культуры, 2012), 37-38. (Latukhinskaia Stepennaia kniga. 1676 g., izdanie podgotovili Nikolai N. Pokrovskii, Aleksei V. Sirenov, otv. red. Nikolai N. Pokrovskii, (Moscow: Iazyki slavianskoi kul'tury, 2012), 37-38).

${ }_{99}^{99}$ Сергей А. Белокуров, О библиотеке московских государей в XVI столетии, Москва: типография Г. Лисснера и А. Гешеля, 1898, 88-89 (Sergei A. Belokurov, O biblioteke moskovskikh gosudarei v XVI stoletii, Moscow: tipografiia G. Lissnera i A. Geshelia, 1898, 88-89). Ср.: Сергей П. Луппов, Книга в России в послепетровское время 1725-1740 (Ленинград: Наука, Ленинградское отделение, 1976), 175, 


\section{7. Итоги}

а. Проведенное исследование позволяет сформулировать как несколько вполне определенных утверждений, так и ряд предположений большей или меньшей степени вероятности. Прежде всего, стало понятно, что своей “теории” о присылке зодчего на Русь Фридрихом Барбароссой автор Истории Российской последовательно придерживался на протяжении не менее десяти лет, до самого конца жизни, несмотря на менявшиеся политические и личные обстоятельства. Более того, он ее ценил и последовательно популяризовал как минимум в трех произведениях, выдержанных в различных жанрах, но в равной мере рассчитанных на требовательную публику. Никакой заведомой мотивации для привлечения к повествованию исторических образов Фридриха I, и тем более Генриха VI, у Татищева не обнаруживается. “Дружба” с ними не добавляла в его глазах величия и престижа владимирским князьям. Тем не менее, в сочинениях Татищева просматривается идеологическая программа, к которой он постепенно приспособил эти исторические фигуры. Политика, предполагающая всемерное приглашение иностранных специалистов, оказывается, глубоко национальна - в том плане, что все выдающиеся правители Руси, включая еще Юрия Долгорукого и Андрея Боголюбского, ее последовательно осуществляли...

б. Гипотетическим “истоком” теории Татищева должен был явиться краткий пересказ послания Генриха VI (“немецкого царя”) Всеволоду Большое Гнездо, в котором император якобы упоминал о “дружбе,” связывавшей его отца с владимирскими князьями, и зодчего (или зодчих), отправленного (отправленных) Фридрихом I некогда Андрею или, скорее, еще Юрию. Соответствующая запись “в оригинале” могла быть датирована 6703 (1195) г. Подлинность этого свидетельства остается под большим вопросом, однако и признаков сознательной мистификации тоже не обнаруживается. Скорее даже наоборот: ключевым для татищевской теории являлось “Примечание Г”, которое мистификатору несложно было бы сформулировать. (Например: “Того же лета приходили ко Всеволоду от царя немецкого по дружбе их...”) Между тем от одной версии текста к другой Татищев только собирался добавить примечание про послов и их грамоту, но так этого и не сделал. Отсюда и возникает впечатление, что автор до последнего надеялся найти потерявшуюся выписку, содержание которой он по памяти пересказывал на разные лады в двух других примечаниях. Там же он поделился как собственным взглядом на “ворота градские" и “соборную церковь” во Владимире, так и впечатлениями некоего иного лица от тех же Золотых ворот и Георгиевского собора в Юрьеве-Польском.

в. Действительно, “теория” Татищева держится не на одном лишь гипотетическом письменном свидетельстве, а на сочетании его с экспертным мнением современника, обратившего внимание историка на три памятника древнерусского зодчества и признавшего в двух из них работу западного мастера. Последнее предполагает предварительное личное знакомство информатора с романским зодчеством где-нибудь в Рейнской области, Ломбардии или, например, Южной Франции. Ведь иллюстрированных альбомов

224, 229. (Sergei P. Luppov, Kniga v Rossii v poslepetrovskoe vremia 1725-1740 (Leningrad: Nauka, Leningradskoe otdelenie, 1976), 175, 224, 229). 
по средневековой архитектуре, а тем более по архитектуре романской, тогда еще нигде не выпускали. ${ }^{100}$ Как выбор Золотых ворот и Георгиевского храма из всех древнерусских памятников, так и сопоставление их между собой - заслуга не Татищева. Однако, видимо, именно он нашел идеологическое обоснование для противопоставления их друг другу как произведений немецкого и булгарского зодчих соответственно. Неизвестный информатор должен был разъяснить историку принадлежность западному зодчему и Успенского собора, ведь путевой журнал Татищева свидетельствует, что "родство” между “соборной церковью” и Золотыми воротами было ему заведомо известно. О том же говорило еще его письмо Шумахеру от 19 ноября 1740 г., в котором предлагалось составить чертежи обоих этих памятников. Однако в примечания к будущей Истории Российской Успенский собор впервые попадет почти годом позже - лишь после посещения его автором. В немецком же “Примечании A" собор еще только подразумевается тем, что слово “строения" (Gebäude) употреблено во множественном числе. Преимущество Золотых ворот состояло, вероятно, в том, что они, по мнению Татищева (а скорее всего еще по мнению его информатора), сохранились существенно лучше, чем “соборная церковь.”

г. В екатеринбургской библиотеке Татищева собрано много книг по фортификации и современному гражданскому строительству. Зато история архитектуры, похоже, его совсем не интересовала, судя по тому, что представлена она была едва ли не одним лишь Витрувием. ${ }^{101}$ Чтобы ориентироваться в этой области, Татищеву, видимо, требовались советы какогото консультанта. Разумеется, любое предположение о личности человека, способного привлечь внимание Татищева к памятникам древнерусской архитектуры, пока обречено оставаться сугубо гипотетическим. Тем не менее понятно, что искать следует авторитетного специалиста, знакомого с итальянскими, немецкими или южнофранцузскими средневековыми памятниками, и в то же время всерьез интересовавшегося историей Руси. В известном нам окружении Татищева легко указать на человека, отвечавшего всем этим требованиям, с которым историк был к тому же знаком немало лет кряду - по меньшей мере с 1731 г. Это упоминавшийся выше Пётр Еропкин “конфидент" Волынского, казненный вместе с ним 27 июня 1740 г. По воле Петра I Еропкин уезжал заграницу - в Голландию, Италию и, возможно, Францию. Известно, что в 1716-1724 гг. он обучался у римского архитектора С. Чиприани (1662-1738).

При нынешних скудных сведениях о биографии Еропкина не удается выяснить даже того, посещал ли он когда-либо Владимир и Юрьев-Польской, ведь его строительная деятельность разворачивалась по большей части в СанктПетербурге, Москве и окрестностях обеих столиц. Разве только владимирские краеведы уверены, что конный двор в Гавриловом Посаде, хотя и возведенный при Екатерине II, был спроектирован еще Еропкиным. Невероятного в этом

\footnotetext{
${ }^{100}$ Само представление о некоем особом “романском искусстве”, как и интерес к нему, появятся лишь в начале XIX в.

${ }^{101}$ Сафронова, Личная библиотека, 278-85. (Safronova, Lichnaia biblioteka, 278-85). В самарской библиотеке Татищева, перевезенной со временем в Москву, книг по архитектуре практически не было: Пекарский, Новые известия, 56-63. (Pekarskii, Novye izvestiia, 56-63). Ср.: Луппов, Книга в Poccuu, 216. (Luppov, Kniga v Rossii, 216).
} 
утверждении нет, особенно если учесть, что Волынский с 1732 г. возглавлял “Конюшенную комиссию” и развил на этом посту энергичную деятельность. ${ }^{102}$ Заботы о Гавриловском конном заводе входили в круг его прямых обязанностей, хотя новое строительство там (в отличие, например, от Хорошевского конного завода) при Волынском так и не началось. Тем не менее, во-первых, авторство Еропкина еще должно быть подтверждено, а во-вторых, типовой проект конного завода архитектор мог начертать и без выезда на место предполагаемого строительства... В чем сомнения нет, так это в том, что Еропкин был великолепным рисовальщиком и умел впечатляюще изображать архитектурные памятники.

Появление Еропкина в качестве гипотетического соавтора “теории” Татищева заставляет всерьез пожалеть об исчезновении принадлежавшего ему экземпляра Степенной книги, как и всего его рукописного собрания. Наибольшие споры вокруг этой коллекции связаны с некоей Полоцкой летописью, о которой Татищев узнал якобы именно от Еропкина. Один эпизод из нее, вошедший в “Историю Российскую”, был еще в XIX в. “разоблачен” как антибироновский памфлет. Татищева при этом следовало считать “или не более, как введенным в обман Еропкиным, или только согласившимся воспользоваться выдумкою последнего." ${ }^{103}$ С этим “разоблачением” согласились далеко не все, и жаркие споры о подлинности Полоцкой летописи продолжаются по сей день. ${ }^{104}$ Кто бы ни оказался прав в конечном счете, Еропкину пока придется оставаться под “источниковедческим подозрением": вдруг он снабжал Татищева “выписками," которые сам же сочинял или смело редактировал? Несложно, впрочем, допустить, что Татищев мог получить цитату про “архитекта”, присланного “немецким царем” и из чьих-либо иных рук, а Еропкин только добавил свою рекомендацию владимирских Золотых ворот ей в подтверждение. Обмениваться историческими находками и наблюдениями было бы естественно в кружке любителей российских древностей, собиравшемся в доме Волынского.

Хотя приведенные сведения не дают никаких оснований обвинить Татищева в сознательной фальсификации, они позволяют высказать к нему, исходя из сегодняшних требований к историческому исследованию, по меньшей мере

\footnotetext{
${ }^{102}$ Подробнее: Игорь В. Курукин, Артемий Волынский (Москва: Молодая гвардия, 2011), 173-79, 183-89, 256-59. (Igor' V. Kurukin, Artemii Volynskii (Moscow: Molodaia gvardiia, 2011), 173-79, 183-89, 256-59).

${ }^{103}$ Николай П. Лыжин, “Два памфлета времен Анны Иоанновны,” Известия Императорской Академии Наук по Отделению русского языка и словесности, т. 7, вып. 1 (Санкт-Петербург: Имп. Академия наук, 1858), 49. (Nikolai P. Lyzhin, "Dva pamfleta vremën Anny Ioannovny," Izvestiia Imperatorskoi Akademii Nauk po Otdeleniiu russkogo iazyka i slovesnosti, t. 7, vyp. 1 (St. Petersburg: Imp. Akademiia nauk, 1858), 49).

${ }^{104}$ Подробный историографический обзор и аргументы в пользу достоверности свидетельств Татищева см. в: Александр В. Майоров, “Из истории белорусского летописания: Полоцкая летопись В. Н. Татищева," Вестник Полоцкого государственного университета, серия А, гуманитарные науки (2005), № 1: 1-19; № 7: 1-16. (Aleksandr V. Maiorov, "Iz istorii belorusskogo letopisaniia: Polotskaia letopis' V. N. Tatishcheva," Vestnik Polotskogo gosudarstvennogo universiteta, ser. A, gumanitarnye nauki (2005), no. 1: 1-19; no. 7: 1-16); Майоров, “О Полоцкой летописи В. Н. Татищева,” Труды отдела древнерусской литературы Института русской литературы Российской Академии наук 57 (Санкт-Петербург: Дмитрий Буланин, 2006), 321-43. (Maiorov, "О Polotskoi letopisi V. N. Tatishcheva," Trudy otdela drevnerusskoi literatury Instituta russkoi literatury Rossiiskoi Akademii nauk, t. 57 (St. Petersburg: Dmitrii Bulanin, 2006), 321-43).
} 
четыре профессиональные претензии. Конечно, в контексте его собственного времени эти претензии вряд ли бы выглядели серьезными.

Во-первых, Татищев сознательно скрыл от академиков свое “открытие” о воздействии Фридриха I на владимирскую архитектуру. Похоже, он осознавал его неординарность и допускал, что профессионалы потребуют предъявить доказательства, которые уже тогда, в конце 1739 г., видимо, были утрачены. ${ }^{105}$ Как бы то ни было, Татищев заменил свое четкое указание на Барбароссу риторическим туманным вопросом о происхождении “архитекта" Андрея Боголюбского. Поправку эту он внес на рубеже 1739 и 1740 гг., когда готовил примечания для перевода на немецкий.

Во-вторых, Татищев неоднократно обманывал ожидания своих потенциальных читателей, обещая им в каждой новой версии своего сочинения привести "ниже" так никогда и не написанное разъяснение о посольстве Генриха VI к Всеволоду. В конце концов он пошел на очевидную хитрость, замкнув примечания “А” и “Б” друг на друга. Вместо этой уловки Татищев мог попросту удалить упоминание “архитекта Барбароссы,” но оно, выходит, представляло для него ценность, которой никак нельзя было пожертвовать.

B-третьих, Татищев произвольно назначил некоего “болгарского” архитектора создателем Георгиевского собора в Юрьеве-Польском. К такому заключению, он, видимо, пришел путем интуитивно расширительного толкования летописного известия, в котором победа над булгарами и возведение юрьевского храма оказались рядом. Кроме того, здесь могли сыграть роль впечатления неизвестного информатора (Еропкина?), быть может, подкрепленные его рисунками, убедившими Татищева в “ориентальном” происхождении строителей. Создав в своем воображении “болгарского” зодчего, Татищев, видимо, всего лишь слегка “дополнил” историческую реальность очевидной ему самому деталью, от которой лишь по сущему недоразумению не сохранилось упоминаний в источниках.

В-четвертых, Татищев, то ли вполне осознанно, то ли, напротив, будучи больным и пребывая уже не вполне в ясном уме и твердой памяти, заменил хорошо ему известную правильную датировку Георгиевского собора на другую фантастическую - ради достижения задуманного идеологического эффекта. Политические пристрастия сильнее обычного потеснили в нем в тот момент академического историка.

е. Свое “открытие” вклада Штауфена в древнерусскую архитектуру Татищев сделал не позже 1739 г., поскольку в “немецкой рукописи” примечаний уже упоминаются некие посланцы Генриха VI к Всеволоду Большое Гнездо. Следующим по времени косвенным указанием на то, что “открытие” уже

\footnotetext{
${ }^{105}$ Вряд ли можно полностью согласиться с мнением, что в то время в Академии некому было раскритиковать присланную Татищевым рукопись. См. Горовенко, Василий Татищев, 112. (Gorovenko, Vasilii Tatishchev, 112). Общими представлениями о Фридрихе Барбароссе, как и вообще о западной истории, должны были располагать П. Л. Леруа, И. Ф. Брем, И. И. Тауберт, Х. Г. Крузиус. См.: Анатолий А. Чернобаев, "Немецкие ученые-историки - члены Российской Академии наук в XVIII в.," Немцы в России. Три века научного сотрудничества (Санкт-Петербург: Дмитрий Буланин, 2003), 125-35. (Anatolii A. Chernobaev, "Nemetskie uchënye-istoriki - chleny Rossiiskoi Akademii nauk v XVIII v.," Nemtsy v Rossii. Tri veka nauchnogo sotrudnichestva (St. Petersburg: Dmitrii Bulanin, 2003), 125-35).
} 
совершено, можно считать ноябрьское письмо 1740 г. с предложением Академии наук обмерить и зафиксировать именно Золотые ворота и юрьевский храм. ${ }^{106}$

Зато ясной нижней хронологической границы татищевского “открытия" выявить пока не удалось. Гипотеза, заслуживающая проверки в первую очередь, состоит в том, что оно случилось в том же 1739 г. в ходе встреч Татищева в столице с другими радетелями о русской истории. Если бы мысль о Барбароссе посетила Татищева еще в Самаре, - скажем, при изучении рукописей, оставшихся после его предшественника на посту главы Оренбургской экспедиции И. К. Кирилова (1695-1737), - то осмотреть Золотые ворота Татищев мог бы еще в январе 1739 г. Стоило только выбрать путь в Петербург через Нижний Новгород и Москву, а не через Ярославль и Вологду, как ему не пришлось бы откладывать знакомство с работой “искусного архитекта" до неведомой будущей оказии. Да и в былые годы Татищеву доводилось проезжать через Владимир, но памятники тогда его, очевидно, не интересовали. Правда, здесь несложно выдвинуть и совсем другую гипотезу: желание взглянуть на Золотые ворота возникло у тайного советника лишь после комментария некоего петербургского знатока средневековой архитектуры (Еропкина?), тогда как необычную строку из “Степенной” (вскоре так некстати утерянную) историк мог обнаружить и раньше - будь то у Кирилова, будь то у очередного раскольника.

Если догадка Татищева об участии Барбароссы в строительстве владимирских Золотых ворот родилась действительно при участии Еропкина, то не ради ли памяти о погибшем приятеле Татищев упорно повторял утверждение, для которого у него не сохранилось никаких доказательств?.. При распродаже конфискованного имущества Волынского Татищев купил, помимо свечных щипцов стоимостью 45 рублей, серебряные подсвечники за 88 рублей. ${ }^{107} \mathrm{He}$ в них ли вносили свечи, когда тесный кружок любителей древней российской истории сходился в гостиной дома на Мойке, чтобы обменяться суждениями о забытых страницах прошлого - вроде той, на которой владимирский князь обзавелся “искусным архитектом" благодаря дружбе с императором Фридерикусом Барбароссой?

\footnotetext{
106 Это письмо свидетельствовало о перемене в настроении Татищева. Всего десятью днями ранее был свергнут Бирон, и историк, справедливо решив, что опасность миновала, возобновил подготовку к публикации Истории.

${ }^{107}$ Курукин, Артемий Волынский, 364. (Kurukin, Artemii Volynskii, 364).
} 